\title{
INFLUENCIA DA ESPÉCIE BACTERIANA E DA TEMPERATURA DA AMOSTRA NO TESTE DE REDUTASE PARA LEITE, COM AZUL DE METILENO E REZASURINA
}

\author{
SILVIA HELENA OLITTA MORATO DO AMARAL
}

Orientador: ANTONIO JOAQUIM DE OLIVEIRA

\begin{abstract}
Dissertação apresentada à Escola Superior de Agricultura "Luiz de Queiroz", da Universidade de São Paulo, para obtenção do título de Mestre em Agronomia - Área de Concentração: Microbiologia Agrícola.
\end{abstract}

PIR A C I C A B A

Estado de São Paulo - Brasil

Setembro, 1985 
ii.

DEDICO

Aos meus pais, inmãs

e madrinha Eline. 


\section{AGRADECIMENTOS}

Ao Prof. Dr. Antonio Joaquim de Oliveira, pela segura orientação e mútua amizade construída na realização deste trabalho.

Aos Profs. Dr. João Gustavo Brasil Caruso e Cláudio Rosa Gallo, pelas sugestões apresentadas e pelo marcante incentivo de amigos.

Aos Profs. Drs. Alcides Martinelli Filho e Hélcio Falanghe, pelos equipamentos cedidos.

Aos Profs. Dr. Humberto de Campos e Cristina stolf Nogueira pela aplicação das Análises Estatísticas.

Aos professores e aos colegas do Curso de Pós-Graduação em Microbiologia Agrícola da Escola superior de Agricultú ra "Luiz de Queiroz", pelo convívio saudável e pela motivação conjunta.

Aos funcionários do Departamento de Tecnologia Rural da Escola Superior de Agricultura "Luiz de Queiroz", pelos valiosos auxílios prestados.

A Coordenadoria de Aperfeiçoamento de Pessoal do Ensino Superior (CAPES), pelo auxílio concedido à partir de 1980 na forma de bolsa de estudos.

Ao Dr. Rubismar Stolf pelo incentivo.

A todos que direta ou indiretamente contribuiram para o êxito deste trabalho. 


\section{INDICE}

Página

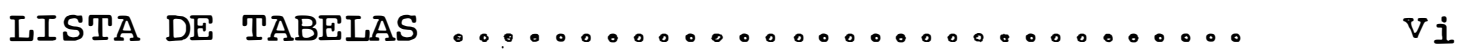

LISTA DE GRAFICOS ................... ix

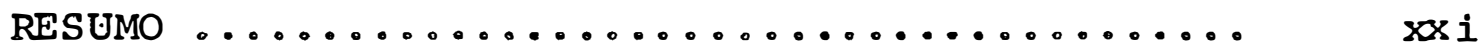

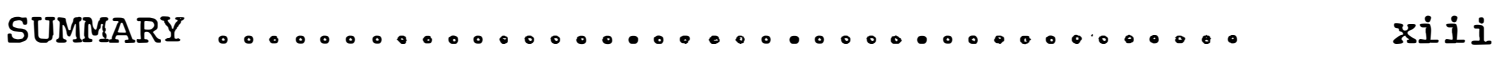

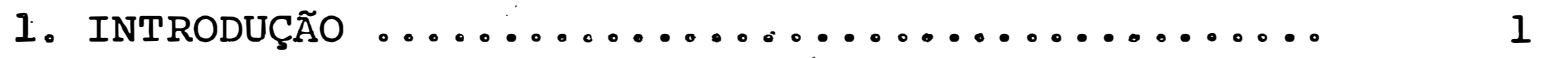

2. REVIISÃo DE LITERATURA .................. 4

2.1. Microrganismos mesofîlicos ............. 4

2.1.1. Coliformes ................. 4

2.1.1.1. Escherichia coli ........ 5

2.1.2. Estafilococos ............... 6

2.1.2.1. Staphylococcus aureus..... 7

2.1.3. Estreptococos ............... 9

2.1.3.1. Streptpcoccus agalactiae.. 9

2.1.3.2. Streptococcus faecalis ... 10

2.1.3:3. Streptococcus lactis ..... 10

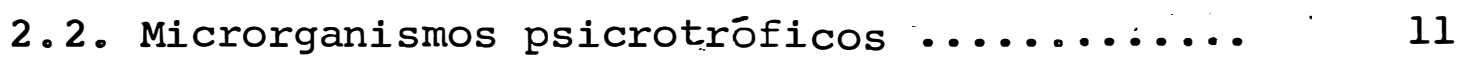

2.2.1. Pseudomonas .................. 14

2.2.1.1. Pseudomonas fluorescens ... 14

2.3. Teste de redutase $\ldots \ldots \ldots \ldots \ldots \ldots \ldots \ldots . \ldots \ldots$

2.3.1. Redução do corante ............. 19

2.3.2. Redução do azul de metileno ....... 20

2.3.3. Redução da rezasurina ........... 22

2.4. Emprego do teste de redutase ........... 23

3. MATERIAL E METODOS .................... 30

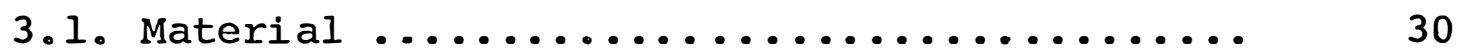

3.1.1. Matéria prima .............. 30

3.1.2. Microrganismos .............. 30 
3.1.3. Corantes .................... 32

3.1.4. Soluções da Escala de McFarland .... 32

3.1.5. Água peptonada ................ 32

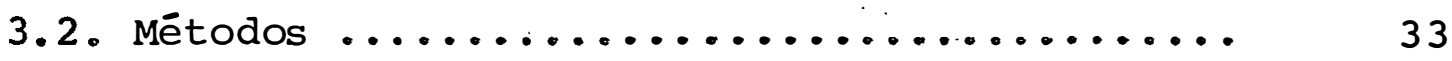

3:2.1. Escala de Mc-Farland ........... 33

3.2.2. Preparo do inóculo :............ 34

3.2.3. Preparo da matéria prima ......... 35

3.2.4. Procedimento experimental ........ 35

3.2.5. Planejamento experimental ....... 36

Análises estatísticas .......... 37

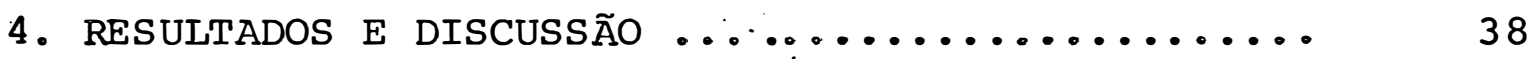

4.1. Escherichia coli IZ 923 e azul de metileno .... 38

4.2. Escherichia coli IZ 923 e rezasurina ....... 42

4.3. Staphylococcus aureus IZ 1974 e azul de metileno 44

4.4. Staphylococcus aureus IZ 1974 e rezasurina ... 47

4.5. Streptococcus agalactiae ATCC 13813 e azul de metileno ....................... 50

4.6. Streptococcus agalactire ATCC 13813 e rezasurina . 55

4.7. Streptococcus faecalis ITAL e azul de metileno - 58

4.8. Streptococcus faecalis ITAL e rezasurina ...... 61

4.9. Streptococcus lactis ITAL e azul de metileno ... 64

4.10. Streptococcus lactis ITAL e rezasurina ...... 67

4.11. Pseudomonas fluorescens ITAL e azul de metileno . $\quad 70$

4.12. Pseudomonas fluorescens ITAL e resasurina ..... 73

5. CONCLUSÕES $\ldots \ldots \ldots \ldots \ldots \ldots \ldots \ldots \ldots \ldots \ldots \ldots \ldots \ldots . .78$

6. LITERATURA CITADA $\ldots \ldots \ldots \ldots \ldots \ldots \ldots \ldots \ldots \ldots . \ldots . \ldots . \ldots . \ldots$

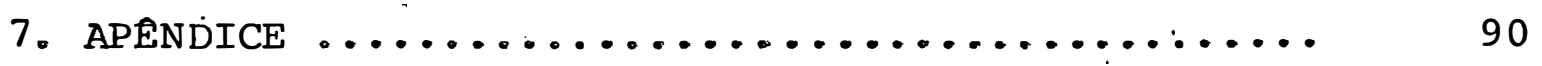




\section{LISTA DE TABELAS}

TABELA NO

pāgina

01 Tempo de redução do corante, azul de metileno - Escherichia coli IZ 923 (minutos).

02

Análise de variância do teste de resutase Escherichia coli Iz 923 e azul de metileno

Tempo de redução do coramte, rezasurina Escherichia coli IZ 923 (minutos) ......

Análise de variância do teste de redutase Escherichia coli Iz 923 e rezasurina....

Tempo de redução do corante, azul de meti leno - Staphylococcus aureus IZ 1974 (minutos)

Análise de variância do teste de redutase - Staphylococcus aureus IZ 1974 e azul de metileno

Tempo de redução do corante, rezasurina Staphylococcus aureus IZ 1974 (minutos).

Análise de variância do teste de reduta se - Staphylococcus aureus Iz 1974 e reza

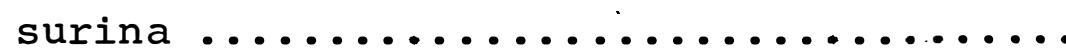

Tempó de redução do corante, azul de meti leno - Streptococcus agalactiae ATCC 13813 (minutos) 
Análise de variância do teste de redutase Streptococcus agalactiae ATCC 13813 eazul de metileno

11

Tempo de redução do corante, rezasurina 56 Streptococcus agalactiae ATCC 13813 (minu tos)

Análise de variânciia do teste de reduta se - Streptococcus agalactiae ATCC 13813 e rezasurịna

Tempo de redução do corante, azul de meti leno - Streptococcus baecalis ITAL (minutos)

14 Análise de variância do teste de reduta se - Streptococcus faecalis ITAL e azul

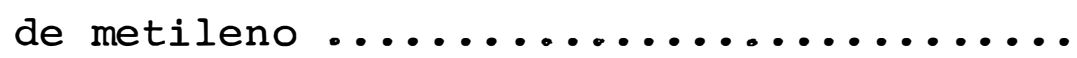

Tempo de redução do corante, rezasurina Streptococcus faecalis ITAL (minutos) ...

Análise de variância do teste de redutá se - Streptococicus faecalis ITAL e reza-

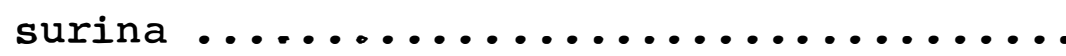

17 Tempo de redução do corante, azul de metí leno - sreptococcus lactis .ITAL (minu-

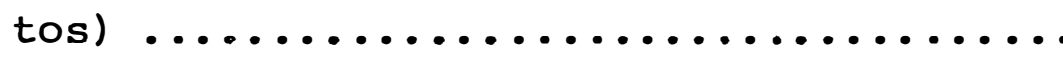


Tempo de redução do corante, rezasurina streptococcus lactis ITAL (minutos) ....

Análise de variância dó teste de redutase Streptococcus lactis ITAL e rezasurina..

21 Tempo de redução do corante azul de metileno - Pseudomonas fluorescens ITAL (minu

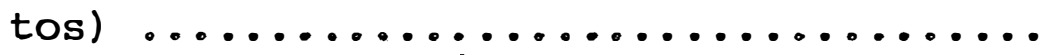

22. Análise de variância do teste de redutase Pseudomonas fluorescens ITAL e azul de me

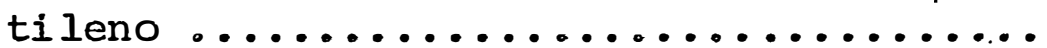

Tempo de redução do corante, rezasurina Pseudomonas fluorescens ITAL (minutos).

Análise de variância do teste de redutase Pseudomonas fluorescens ITAL e rezasurina 
ix.

\section{LISTA DE GRAFICOS}

GRÁFICO NO

pāgina

01 Comportamento da Escherichia coli Iz 923

e azul de metileno .................

Comportamento da Escherichia coli IZ 923

e rezasurina

Comportamento do Staphylococcus aureus IZ 1974 e azul de metileno ..............

Comportamento do Staphylococcus aureus IZ

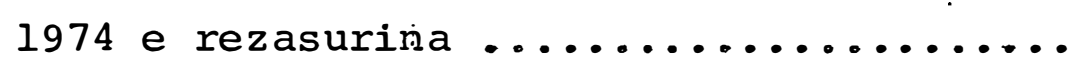

Comportamento do Streptococcus agalactiae ATCC 13813 e azul de metileno ..........

Comportamento do Streptococcus agalactiae ATCC 13813 e rezasurina .............

Comportamento do Streptococcus faecalis ITAL e azul de metileno ...............

08

Comportamento do Streptococcus faecalis ITAI e rezasurina

Comportamento do Streptococcus lactis ITAL e azul de metileno ............... 
12 Comportamento da Pseudomonas fluorescens

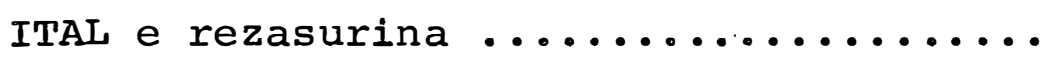


INFLUENCIA DA ESPECIE BACTERIANA E DA TEMPERATURA DA AMOSTRA NO TESTE DE REDUTASE PARA LEITE COM AZUL DE METILENO E REZASURINA

Candidata: SILVIA HELENA OLITTA MORATO DO AMARAL Orientador: ANTONIO JOAQUIM DE OLIVEIRA

\section{RESUMO}

A influência da espécie bacteriana e da temperatura da amostra na descoloração dos corantes azul de metileno e rezasurina normalmente empregados no teste de reduta se para se avaliar a população bacteriana do leite, ao chegar à plàtaforma da indústria, foi estudada.

Para tal foram elegidas seis culturas de microrganismos que normalmente estão presentes em leite cru, como descritos por vários autores FOSTER et alii. (1957), DONNELLY (1968), BABEL (1953), MARTH \& FRAZIER (1957). Essas cul turas são: Escherichia coli, Staphylococcus aureus, streptococ cus agalactiae, Streptococcus faecalis, Streptococcus lactis, Pseudomonas fluorescens.

As temperaturas iniciais das amostras, foram escolhidas baseando-se no uso ou não de resfriamento na propriedade e no tempo decorrido entre ordenha e recebimento do leite na plataforma. Desta forma trabalhou-se com 50, 100, 150, 20, 25, $30^{\circ}$ e 350 C, como temperaturas iniciais das amostras. 
o inóculo foi preparado de culturas puras de cada espécie de microrganismos, baseando-se na escala de McFarland, pela leitura espectrofotométrica a $420 \mathrm{~nm}$, comparada com o tubo no 4 da referida escala e que corresponde a uma população de $4,5 \times 10^{8}$ bactérias $/ \mathrm{ml}$.

Após acertada a população bacteriana inicial, $1 \mathrm{ml}$ das suspensões era inoculado em $8,0 \mathrm{ml}$ de leite esterelí zado já ajustado à temperatura desejada em tubos de cultura com tampa de rosca. Nestes eram adicionadosl,0 ml da solução do corante e imediatamente levadós à incubação em banho maria a $370 \pm 0,2 \circ \mathrm{C}$.

O tempo de redução do corante pelos microrganis mos foi avaliado pela diferença do tempo de entrada da amostra no banho-maria, até a descoloração total (forma leuco), pa ra ambos os corantes.

A análise estatística dos resultados mostrou que os microrganismos se comportaram diferentemente em relação à temperatura inicial da amostra e ao tempo de descolora ção dos corantes, com variações que não permitem apontar o co rante mais adequado para o teste de redutase em relação à tem peratura da amostra. 
BACTERIAL SPECIE AND SAMPLE TEMPERATURE INFLUENCE ON THE REDUCTASE TEST FOR MILK WITH METHYLENE BLUE AND REZASURINE

Candidate: SILVIA HELENA OLITTA MORATO DO AMARAL Adviser: ANTONIO JOAQUIM DE OLIVEIRA, Ph.D.

\section{SUMMARY}

This work was undertaken to study the influence of bacterial species and the sample temperature on the reduction of methylene blue and rezasurine dyes usually used for the reductase test, to check the milk bacterial population at its arriving at the dairy plant.

Six microorganisms species reported by many authors FOSTER et alii (1957), DONNELLY (1968), BABEL (1953), MARTH \& FRAZIER (1957) as usually found in raw milk were selected. These cultures were: Escherichia coli, Staphylococcus aureus, Streptococcus agalactiae, Streptococcus baecalis, Stre ptotoccus lactis, Pseudomonas buorescens.

The temperatures of the samples were chose based on the use or not of refrigeration of the milk at the dairy farm and on the time elapsed from milking untill the arrive of the milk at the plant. Though, the temperature of the samples were ajusted to $50,100,150,200,250,300$ and $350 \mathrm{C}$, before testing: 
The inocullum was prepared from pure cultures of each specie of microorganism, based on the Mc Farland ' $s$ scale, by the spectrofotometric reading of a suspension of microorganism at $420 \mathrm{~nm}$, compared to the $\mathrm{n}$ ? 4 tube of this scale, which represents a population of $4.5 \times 10^{8}$ bacteria /ml. The reductase test was performed by inoculating $1.0 \mathrm{ml}$ of the microbial suspension prepared as previously in $8.0 \mathrm{ml}$ of steril milk ajusted to the desired temperature, in screw capped tubes and addiction of $1.0 \mathrm{ml}$ of the dye tested. Then the tubes were immediatly put into the water-bath $370 \pm 0,20 \mathrm{c}$. The reduction time was taken as the diference between the time of mixting the dye with the sample and the complete reduction of the dye.

The statistical analyses of the results show a different behavier among the microorganism tested, as related to the initial temperature of the sample and the reduction time of the dye, the variations were such, that make it difficult to point out which dye was more adequate for the reductase test in relation to the initial temperature of the sample. 
1. INTRODUÇ̃̃O

A boa qualidade dó leite destinado ao consumo é fator de suma importância, visto que o leite é considerado uma das principais fontes de nutrientes para uma grande parte da população. Seu valor está baseado fundamentalmente em seu quase perfeito balanço de nutrientes, riqueza em minerais e valor energético.

Estas características por outro lado tornam-no um dos alimentos mais susceptíveis de sofrer alteraçöes físico-químicas e deterioração por microrganismos oriundos de diferentes fontes.

Entre os microrganismos que provocam alterações no leịte, os mais importantes são as bactérias como Strep tococcus lactis, Streptococcus faecalis, Lactobacillus sp., Clostridium sp, Pseudomonas sp, Bacillus sp, Escherichia co$l i$, etc; os quais poder produzir azedamento ou formação de ácido, formação de gás, proteólise, aumento da viscosidade, lipólise e alteração na cor e sabor. 
De excelente alimento que é, o leite pode se tornar um veículo de transmissão de doenças que são comuns aos animais e ao homem como é o caso da tuberculose, aftose, brucelose e outras.

Desta forma, torna-se de maior importância o controle do estado de saúde dos animais em ordenha, bem como a manutenção de condições de higiene as melhores possíveis du rante a ordenha, beneficiamento e distribuição do leite, para que um produto de qualidade chegue ao consumidor.

A qualidade microbiológica do leite pode ser detectada por diferentes métodos, os quais envolvem técnicas mais ou menos complexas, de acordo com as necessidades da aná lise. Dentre esses métodos, o teste de redutase é o de maior aplicação prática sendo, segundo a portaria número 005 de 24 de abril de 1980, publicada no Diário oficial da União, ano CXVIII, baixada pela Divisão de Inspeção de Leite e Derivados (DILEI) da Secretaria da Inspeção de Produto Animal (SIPA) do Ministério da Agricultura; "a prova da redutase do leite deve ser efetuada através do corante azul de metileno, no mínimo duas vezes por semana, por produtor, não devendo o tempo de descoloração ser inferior a duas horas e trinta minutos".

Reforçando, o Ministério da Agricultura, estabeleceu recentemente a portaria no 06 de 7 demarço de 1983, publicada no Diário Oficial da União, ano CXXI no 49 para, leite "in natura", após sua chegada ao estabelecimento recebedor do leite, torna-se obrigatório o teste de Redutase, seguindo-se 
outras providências tais como: condições de higiene do veículo e do toldo; inspeção dos latões para transporte do leite; a seleção do leite pelo alizarol com mínimo de 689GL; os caracteres organolépticos do leite; a eventual aguagem através da verificação do extrato seco e prova da crioscopia; a pesquisa do colostro, pus, sangue, fervura, conservador e/ou ini bidor, neutralizante, reconstituintes da densidade e lactofiltração.

Por essa mesma portaria, torna-se também obrigatório o teste da Redutase, em leite pré-beneficiado.

A prova de redutase auxilia na seleção do leite recebido, avaliando-se indiretamente o seu conteúdo microbiano através da velocidade de descoloração de soluções de determinados corantes pela ação enzímica dos microrganismos presentes.

Como finalidades básicas do presente trabalho destacam-se:

- A influência da espécie de microrganismo na aplicabilidade do teste de redutase para medir a qualidade microbiológica do leite, quando se empregam os corantes azul de metileno e rezasurina.

- Influência da temperatura da amostra no momento da realização do teste de redutase quando se tem diferentes espécies de microrganismos presentes. 


\section{REVISÃO DE LITERATURA}

\subsection{Microrganismos mesofilicos}

As bactérias conhecidas como mesofilicas, são microrganismos que se multiplicam numa faixa de temperatura en tre 20-409C, śendo que algumas espécies podem se desenvolver à temperaturas inferiores à 100C (BUCHANAN e GIBBONS, 1974).

\subsubsection{Coliformes}

São bactérias normalmente utilizadas como indi cadoras da qualidade sanitária dos alimentos porque estão em maior número no trato intestinal em relação à outros microrganismos e crescem bem em vários substratos, tornando-se fácil o seu desenvolvimento (FRAZIER, 1967). Essas bactérias também estão altamente relacionadas com os patogênicos intestinais presentes nos alimentos. Assim, a presença de bactérias desse grupo, indicará as condições do tratamento térmi- 
co feito, falta de sanificação dos equipamentos e manuseio ina dequado (ASHTON, 1950).

Os principais microrganismos coliformes são:

Escherichia coli e Aerobacter aerogenes as quais pertencem à família Enterobacteriaceae. Ambas são bastonetes curtos, gram - negativo e fermentam a lactose com produção de gás, sendo diferenciadas por testes bioquímicos (JAWETZ et alii, 1970). Além da Escherichia coli, proveniente do trato intestinal, temos também representantes dos gêneros: Klebsiel la, Salmonella e Shigella, que demonstraram ser patogênicos quando alcançam os tecidos fora do trato intestinal, como, trato urinário, trato biliar, peritônio ou as meninges, causando infecções (JAWETZ et alii, 1970).

Embora, possam se desenvolver a temperaturas en tre $4^{\circ}$ e $100 \mathrm{C}$, quando incubadas à $22^{\circ}$ e $300 \mathrm{C}$ essas bactérias tem o seu desenvolvimento favorecido no leite, mas à $370 \mathrm{C}$ apresen tam um crescimento ligeiramente retardado (ASHTON, 1950).

\subsubsection{Escherichia coli}

Apresentam-se na forma de bastonete retos, medindo 1,1 a 1,5 por 2,0 a $6,0 \mu \mathrm{m}$. Móveis por meio de flagelos peritríquieos ou imóveis. são gram-negativo, crescem fa cilmente em meio de cultura simples (PELCZAR et alii, 1981).

Tem como temperatura ótima 320C, fermentam a lactose com formação de ácido e gás. Na ausência de hidrato de carbono fermentável são ligeiramente proteolíticos, produ- 
zindo indol, 35\% de ácido lático e outros compostos como etanol, ácido acético, ácido succínico, anidrido carbônico e hidrogênio. (FOSTER et alii, 1957).

Dois são os tipos de Escherichia coli enteropatogênicas que podem causar desarranjos de origem alimentar: invasivos e enterotoxinogênicos (FRANK, 1978). As poucas informações sobre a incidência de doenças produzidás por esse microrganismo enteropatogênico, está na dificuldade em diagnỏsticā-la (SACK, 1975), e se detectar sua presença nos alimentos, por problemas no seu isolamento. (MEHLMAN, 1974L, bem como a verificação da patogenicidade dos isolados (MEHLMAN, 1976.).

Quando ingerida juntamente com os alimentos a Escherichia coli causa infecçöes intestinais (MEHLMAN et alii 1976; MARIER, 1973) e está mais frequentemente associada com diarréias infantis. (RYDER, 1976).

são fontes de contaminação desse microrgamismo, o esterco, utensílios, solo, metabólitos do trato intestinal humano e de animais vertebrados. Sendo f́acilmente destruída no processo de pasteurização, a Escherichia coli é considera da indicadora da qualidade sanitária na indústria leiteira, podendo provocar alterações de sabor e aroma no leite e derivados (FOSTER et alii, 1957).

\subsubsection{Estafilococos}

Pertencentes a família Micrococaceae aparecem 
sob a forma de células esféricas medindo 0,5 a 1,5 $\mu \mathrm{m}$ de diâmetro, ocorrem isoladamente ou aos pares, com divisão característica.em mais de um plano. Tem metabolismo respiratório e fermentativo, anaeróbios facultativos, crescem melhor em condiçōes de aerobiose. A temperatura ótima para seu desenvolvi mento está entre $35 \circ-40 \circ \mathrm{C}$. Principalmente associados com a pele, glândulas cutâneas e mucosas de animais de sangue quente (PELCZAR et alii, 1981)..

Produzem enterotoxinas dos tipos: A, B, C, D; E e.F. (BERGDOLL, 1979); as quais, quando ingeridas juntamente com alimentos provocam intoxicações com os seguintes sintomas: nāuseas, vômitos, diarréias e cólicas abdominais, desidratação, prostação e excessiva transpiração; sem ocorrência de febre, essas perturbações não duram mais que dois dias (BRYAN, 1973L.

A temperatura ótima para crescimento situa-se

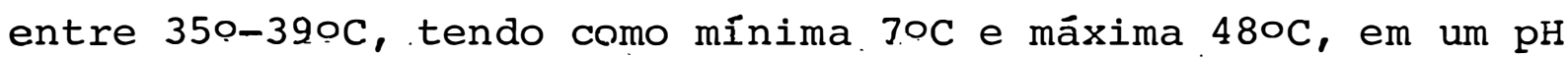
de 9,5-9,8, a produção de enterotoxina ocorre à 100 e $480 \mathrm{C}$ em $\mathrm{pH}$ normalmente de 5,3-6,8 (TROLLER, 1976).

\subsubsection{Staphylococcus aureus}

As principais fontes de contaminação desse microrganismo são: descargas nasais e da garganta, mãos, pele, cortes infeccionados, fezes, etc.; chegando aos alimentọs por falta de cuidados higiênicos no manuseio (BRYAN, 1973).

Essà bactéria é a que mais tem sido constata- 
da em casos de intoxicações alimentares, causadas por leite e derivados. Outros veículos desses microrganismos, são também càrnes preparadas (FRAZIER, 1967).

o tipo mais frequente de intoxicação alimentar é causado pelas enterotoxinas termoestáveis, produzida quando esse microrganismo cresce em alimentos rico em carboi dratos (JAWETZ et alii, 19.70). A faixa de temperatura para produção da toxina é de $15,60-46,10 \mathrm{C}$, sendo a maior produção encontrada entre $21,10-36,10 \mathrm{C}$. Sob condições ótimas, essa toxina demora de quatro a seis horas para tornar-se detectável (FRAZIER，1967)。

Embora a ințoxicação cauisada por esse microrga nismo se caracterize por baixa mortalidade, a frequência dos casos e a severidade dos sintomas, fazem desse tipo de intoxicaçầo, uma importante doença oriunda de vários tipos de alimentos (TROLLER, 1976)。

Staphylococcus aureus raramente atinge altas contagens quando presente no leite cru, mas prosperam e produzem enterotoxina no leite pasteurizado (DONNELLY, 1968). Es se microrganismo desenvolve-se bem em meios de cultura sintéticos em condições aeróbicas e anaeróbicas, produzindo toxina anąerobicamente. Nos alimentos, o créscimento e formação de toxina podem ocorrer sob condições anaeróbicas, mas se proces sam melhor na presença de oxigênio. As contagens de StaphyLococcus aureus devem ser de $10^{7}-10^{8}$ células/g de alimento para que se produza a quantidade de enterotoxina detectável pelos atuais métodos de análise (TROLLER, 1976). 
Segundo TAKAHASKI (1959) o soro oriundo da fabricação de queijo apresenta baixa população de Staphylococcus aureus, sugerindo que a maioria fica retida no coágulo.

\subsubsection{Estreptococos}

Aparecem como células esféricas ou ovais com aproximadamente $2 \mu \mathrm{m}$ de diâmetro, dispõem-se aos pares ou em cadeias. Não tem motilidade, não formam endosporos, são gram-positivo; e apresentam metabolismo fermentativo para ácidos lático, acético e fórmico. Suas necessidades nutricionais são complexas e variadas. Anaeróbicos facultativos, tem seu ótimo de desenvolvimento à $370 \mathrm{C}$ (BUCHANAN e GIBBONS, 1974).

\subsubsection{Streptococcus agalactiae}

são microrganismos associados com leite e teci dos do úbere de vacas que apresentam mastite, bem como com várias infecções humanas. Quạdo desenvolvem em meio contendo glicose o pH. final atinge 4,2 e 4,8. Produzem ácidos a partir de glucose, maltose, sacarose e fermentam o glicerol anaerobicamente. A lactose é fermentada por strains oriundos de isolados de outros animais e humanos. A temperatura ótima para seu desenvolvimento é 370C (BUCHANAN e GIBBONS, 1974); porém, são destruídos na pasteurização (FOSTER et alii, 1957). Apresentam necessidades nutricionais complexas quanto a vitaminas e aminoácidos (BUCHANAN e GIBBONS; 1974). 


\subsubsection{Streptococcus faecalis}

Apresentam-se na forma de colônias lisas, rara mente pigmentadas, formam cadeias, fermentam a glicose primei ramente em ácido lático. Em meio de cultura contendo glicose o pH final está entre 4,1-4,6 (BUCHANAN e GIBBONS, 1974).

A faixa de temperatura para seu desenvolvimento está entre 100e 450C. São vias de contaminação as fezes humanas e de animais vertebrados, aparecendo ocasionalmente no trato urinário, leite cru e pasteurizado (FOSTER et alii, 1957):

\subsubsection{Streptococcus lactis.}

Segundo FOSTER et alii (1957) quem primeiramen te o descreveu foi Lister.

Formadores de ácido a partir da glicose, malto se, lactose. PH final em meio de cultura contendo glicose es tá entre 4,0-4,5. Alguns strains produzem antibiótico, inibindo muitos microrganismos gram-positivo. Desenvolvem-se em meio de cultura contendo até $4 \%$ de $\mathrm{NaCl}$. Tem crescimento ini cial em pH 9,2 e não são capazes de desenvolver em leite contendo $0,3 \%$ de azul de metileno. Sua temperatura ótima é de 309̣c, sendo que alguns strains crescem. à $410 \mathrm{C}$, mas não à $45{ }^{\circ} \mathrm{C}$ (BUCHANAN e GIBBONS, 1974).

Contaminante comum do leite e derivados, são microrganismos essenciais para a fabricação de queijos e leites fermentados, sendo também considerados auxiliares na pre servação de certos produtos lácteos. 
Quando fermentam a lactose contribuem com 0,8 à 1,0\% de ácido lático e quantidades traços de ácido acético e propiônico, sendo que a produção diminue com a aeração (FOS TER et alii, 1957).

\subsection{Microrganismos psicrotróficos.}

O termo psicrotrófico é utilizado na 13ạ edição do Standard Methods for the Exxamination of Dairy Products (1972), para indicar os microrganismos que são capazes de for mar colonias visíveis em meio nutriente agar quando incubados à 7ec por dez dias.

Há mais ou menos uma década atrás, psicrotrófí co no leite eram chamados de psicrófilos e afirmava-se serem destruídos, em uma pasteurização (ROGICK, 1972; ANDREWS, 1953; WITTER, 1961).

EDDY (1960) sugeriu que o termo psicrotrófico fosse usado para indicar os microrganismos que são capazes de crescer a baixas temperaturas.

$\mathrm{Na}$ indústria de laticínios onde grandes volumes de leite ficam armazenados à temperaturas de refrigeração por longos períodos, as bactérias psicrotróficas podem desenvolver causando mudanças indesejáveis no leite e nos seus derivados. A presença desses microrganismos indica a baixa qua liaaacie do leite e insatisfatórias condições sanitárias no prọ cessamento (ANDREY, 1959;. MOSE, 1968). 
Podem causar sérios danos eln leite e derivados quando estocados a temperaturas que vão de $10-70 \mathrm{C}$

(ELLIKER 1964; FORD, 1969; LUCK, 1972; THOMAS, 1966).

o termo psicrófilo é empregado para designar os microrganismos que tem temperatura ótima de crescimento 150C ou menos, sendo a máxima $20 \circ \mathrm{C}$ e a mínima 0ọ ( THOMAS 1969).

Segundo THOMAS (1969), de acordo com as normas da International Dairy Federation, psicrófilos de leite e derivados são definidos como microrganismos que se multiplicam a $70 \mathrm{C}$ ou menos independentemente da temperatura ótima de cres cimento.

Os psicrotróficos presentes no leite cru comer cial são aqueles pertencentes aos gêneros Pseudomonas, Flavobacterium, Achromobacter. (BABEL, 1953).

Segundo THOMAS et alii (1961) comparando-se a contagem de colônias desses microrganismos incubados à 30-50C, por dez dias e $70^{\circ} 0$ 0,50C nesse mesmo período de tempo; de uma série de cento e dezessete amostras de leite esterilizado, ve rificou-se um maior número de colônias nas amostras incubadas à 70C. Desta forma a A.P.H.A. (1972) recomenda para contagem de psicrotróficos as condições acima mencionadas. Por outro lado, OLIVEIRA e PARMELLE (1976), verificaram que esses microrganismos no leite desenvolvem-se à temperatura de $210 \mathrm{C}$, enquanto as mesofílicas crescem lentamente, assim a incubação à $210 \mathrm{C}$ por vinte e cinco horas. é equivalente ao tratamento de 7oC por dez dias. 
Tem sido verificado, que um reduzido número desses microrganismos sobrevive à pasteurização e esterilizą ção (GROSSKOPF, 1969; WATROUS, 1971; PATEL, 1972; WITTER 1961). Segundo esses mesmos autores, o leite pasteurizadode ve ser estocado à $70 \mathrm{C}$ por uma semana, antes dos psicrotróficos resistentes ao calor poderem ser detectados (tempo necessário para o reparo das células danificadas).

JUFFS e BABEL 1975) utilizando culturas láti-. cas para inibir às bactérias psicrotróficas, verificaram ser - Leuconostoc cremoris a mais efetiva.

De acordo com OVERCAST (19.74) o crescimento de bactérias gram-negativa no leite antes do processamento, estimula o desenvolvimento de microrganismos psicrotróficos for madores de esporos.

Segundo MARTH e FRÄZIER (1957) o número desses microrganismos no leite é utilizado para se avaliar a qua lidade do produto, entretanto (BABEL, 1953) relata que, quando o leite é mantido à $4,4 \circ \mathrm{C}$, a acidez só se eleva significativamente quando uma elevada população de psicrotróficos está presente.

Considerando a habilidade respiratória desses microrganismos, segundo MORITA (1975) esta diminue durante 0 tratamento inicial pelo calor nas temperaturas próximas ou li geiramente acima da máxima de crescimento.

De acordo com ZACHARIAH e LISTON (1973) a adaptação à temperatura, apresenta-se como um fenômeno entre es- 
sas bactērias, sugerindo que ocorrem trocas bioquímicas nas células, transferindo-se a capacidade de desenvolverem a baixas temperaturas, bem como a de metabolizar substratos.

\subsubsection{Pseudomonas.}

Dentre os psicrotróficos, uma das famílias de bactérias mais importantes é a Pseudomonadaceae contando com aproximadamente ćento e quarenta e nove espécies.

As bactérias dessa família são bastonetes, gram negativo, móveis, não esporulados (FRAZIER, 1967). Apresentam metabolismo respiratório, nunca fermentativo, tendo o oxigênio molecular como recptor de elétrons, sendo que algumas espécies utilizam nitratos como aceptores alternativos; são aeróbios estritos (PELCZAR et alii, 1981). Podem se desenvol ver entre 00-37\%c, dependendo da espécie considerada, embora a temperatura ótima para o crescimento seja $210 \mathrm{C}$.

São importantes na deterioração de alimentos como: carneș, ovos, produtos do mar e leite, quando conservados sob refrigeração. As espécies de importância na microbiologia do leite são: Pseudomonas fluorescens, Pseudomonas fragi, Pseudomonas nigrefaciens, Pseudomonas putrefaciens, Pseu domonas viscosa (FOSTER et alii, 1957).

2.2.1.1. Pseudomonas fluorescens

são microrganismos que decompõ̉em vários tipos 
de substratos, apresentam pronunciada atividade bioquímica em especial com as proteínas e pouca atividade fermentativa em relação aos hidratos de carbono, sendo as mudanças por elas produzidas do tipo oxidativas (FOSTER et. alii,.. 1957).

Colorem o meio de cuitura em um tom verde-pardo (FOSTER et alii, 29.57). Segundo LEISINGER e MARGRAFF (1979) trata-se de um pigmento fluorescente denominado pyoverdine, sen do sua emissão máxima à 500nm. o pigmento fluorescente da Pseudomonas fluorescens consisțe de serina, glicina, ácido glutâmico, ornitina e lisina, sendo este o resultado do metabolismo da própria bactéria.

Segundo MORITA (1975) a Pseudomonas fluorescens tem como temperatura ótima de crescimento $150 \mathrm{C}$ e máxima $250 \mathrm{C}$. Entretanto, a melhor produção de células já descrita na literatura foi de $9 \times 10^{8}$ à $200 \mathrm{C}$ por setenta e duas horas.

Em leite e derivados mantidos sob temperatura de refrigeração, podem conferir sabor amargo aos produtos. São fonte de contaminação dessa espécie; o solo, água, utensí lios e equipamentos (FOSTER et alii, 1957).

\subsection{Teste de redutase}

Segundo BARKWORTH, IRWIN e MATTICK (1941), até 1937 o leite na Inglaterra era classificado por meio de conta gem em placas, embora os bacteriologistas já estivessem cien- 
tes dos erros e desvantagens desse método, que de certa forma impedia a caracterização do leite em uma faixa mais ampla. Dada as dificuldades da contagem por semeadura, o teste de redução de corantes foi introduzido na rotina industrial, pas sando a ser usado em larga escala.

Em janeiro de 1937 o Ministério da Saúde da Inglaterra abandonou o uso da técnica de contagem em placas, substituindo-a pelo teste de redutase, considerando:a descolo ração total no leite à temperatura estipulada. Por outro lado, o efeito da temperatura sobre ô crescimento bacteriano é no tório, evidenciando muito pouco quando comparada à contagem em placas.

Para DEMETER (1969), a redução dos corantes cons tituem uma prova específica do estado de frescor do leite cru e sua capacidade de conservação frente à acidificação, sendo uma forma de se determinar o conteúdo geral de germes. Ofere cem tambêm uma maior concordância dos microrganismos em leite comercial, onde hâ uma coincidência com o grau de acidez. As sim em 90\% dos casos o tempo de redução ocorre onde há flora contendo bactérias mesófilas produtoras de ácido lātico.

Esse mesmo autor considera que as provas se apresentam mais imprecisas quanto maiores forem as oscilações na flora devido à influência de fatores como: leite pobre em germes vindo de somente um estábulo ou de um animal, leite pasteurizado, taxa de leucócitos, estações do ano, ordem de ordenha (manhã ou tardel, resfriamento prolongado no qual 
há o desenvolvimento de psicrófilos (baixa atividade de redução), higiene empregada na manipulação do leite, etc.

A diferença nos métodos bacteriológicos de determinação de microrganismos está baseada nas condições climá ticas e composição da flora microbiana, não se podendo estabelecer uma caracterização satisfatória do leite tomando como base somente a prova de redução, visto que, a amplitude de va riações no número de microrganismos é muito grande para o mes mo tempo de redução.

Segundo SOLBERG et alii (1974) o teste baseia-se no. fato da maioria das bactérias que se desenvolvem no leite, abaixarem o potencial de oxidação-redução, provocando mudança da cor de certos corantes, estimando indiretamente o número de bactérias nas amostras de leite, as quais determinam mu danças no substrato causadas pela atividade metabólica, diminuindo a quantidade de oxigênio dissolvido e pela produção de metabólitos e enzimas específicas.

De acordo com Standard Methods for the Examination Dairy 'Products (A.P.H.A., 1978) o tempo de redução deve ser inversamente proporcional à população bacteriana, $\circ$ que foi comprovado comparando-se a variação do tempo de redução com as populações bacterianas determinadas, por outros métodos: Por outro lado, leites contendo números equivalentes de bactérias podem ser reduzidas a diferentes tempos, dependendo da fase de crescimento predominante da bactéria.

A aplicação do teste permite classificar as 
amostras em dois ou mais grupos, de acordo com as diferenças das espécies bacterianas, mas para colostro, leite evaporado e leite de animais em adiantado estágio de lactação, o tempo de redução não é proporcional à população bàcteriana. Entretanto, o teste permite um melhor controle rotineiro de traba1ho.

Espécies bacterianas, como por exemplo, o Streptococcus lactis, reduz rapidamente o corante, sendo utilizado para detectar leites de qualidade inferior (HAMER, 1948), enquanto as proteolîticas tem pequeno poder de redução (SCHNERR 1959).

Segundo o Standard Methods for the Examination Dairy Products (A.P.H.A., 1978), o teste pode ser influenciado por fatores como:

- diferença na atividade de redução de espécies bacterianas quando a' amostra é incubada à $360^{\circ} \pm 1,0 \circ \mathrm{C}$. Por exemplo, a maioria das bactérias termoduricas são menos ativamente redū toras do que muitas de outras contaminantes comuns do leite que são prontamente detectadas no teste de redutase. o mesmo ocorrendo com as bactérias psicrotróficas.

- variação na proporção de bactérias que se deslocam na camada de creme pela elevação dos glóbulos de gordura.

- presença de substâncias inibidoras, como resíduos de antibióticos, do tratamento da mastite bovina. 


\subsubsection{Redução do corante}

Segundo FOSTER et alii (1957), os métodos de redução de corantes baseiam-se na capacidade que certos microrganismos tem de alterar o potencial de oxidação - redução do meio. Ele é fundamentalmente uma médida na tendência de um sistema reversível de liberar e captar elētrons, sendo a oxidação um processo que se comporta como perda de elétrons e a redução admis̄são de elétrons.

Em sistemas biológicos tais como cultivo de microrganismos, as reduções e oxidações simultâneas são fonte de energia para os processos celulares.

As oxidações biológicas são mais entendîveis considerando que há uma perda de hidrogênio ou ganho de oxigênio, cada uma das quais equivalendo a uma perda de elétrons.

Compostos como glutationa, cisteina, ácido ascórbico, azul de metileno e rezasurina podem servir de aceptores de hidrogênio para muitas bactérias que necessitam dos sistemas de.enzimas, tal como o citocromo, para utilizar ooxi gênio como receptor de hidrogênio. Esses compostos podem também ser utilizados por microrganismos, nos quais o oxigênio é ordinariamente o receptor final, quando esses se encontram sem oxigênio livre.

Geralmente, os meios de cultivo são redutơes, isto é, tem baixo potencial de. oxi-redução quando em ausência de oxigênio e potencial elevado quando está em equilíbrio com esse elemento. 
De acordo com esses mesmos autores, a redução do azul de metileno e da rezasurina nas provas de redutase depende da capacidade dos microrganismos presentes nos produtos lácteos, para produzir condições redutoras no meio em que estão proliferando.

Por outro lado, a inversão dos tubos exatamente no momento da redução atrasa frequlentemente a mudança da cor, pela introduçãc de oxigênio, elevando o potencial de oxiredução.

\subsubsection{Reducão do azul de metileno}

o princípio da redução do azul de metileno foi desenvolvido por Barthel e Orla-Jensen em 1912 (INTERNATIONAL DAIRY FEDERATION, 1974 ).

Esse corante é encontrado no comércio como clo reto de sódio mais cloreto de zinco, representado pela fórmula: $2 \mathrm{C}_{16} \mathrm{H}_{18} \mathrm{~N}_{3} \mathrm{SCl}+\mathrm{ZnCl}_{2}+\mathrm{H}_{2} \mathrm{O}$ recebendo a designação de 3,9Bisdismethylamino-phenazothionium chloride, apresentando a se guinte estrutura quỉmica.

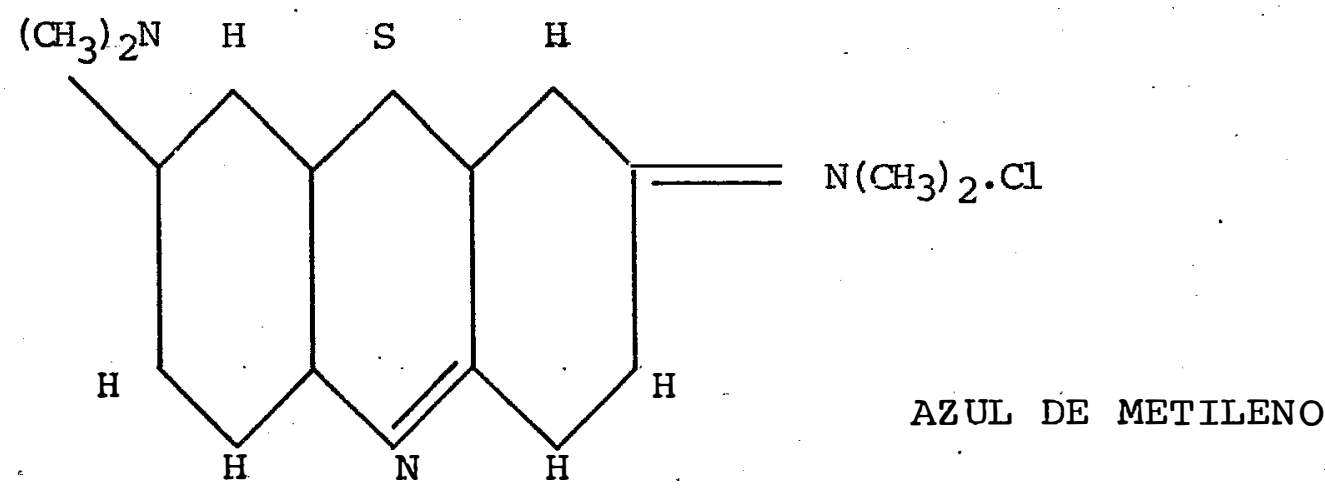


Na forma reduzida:

$\left(\mathrm{CH}_{3}\right)_{2} \mathrm{~N}$

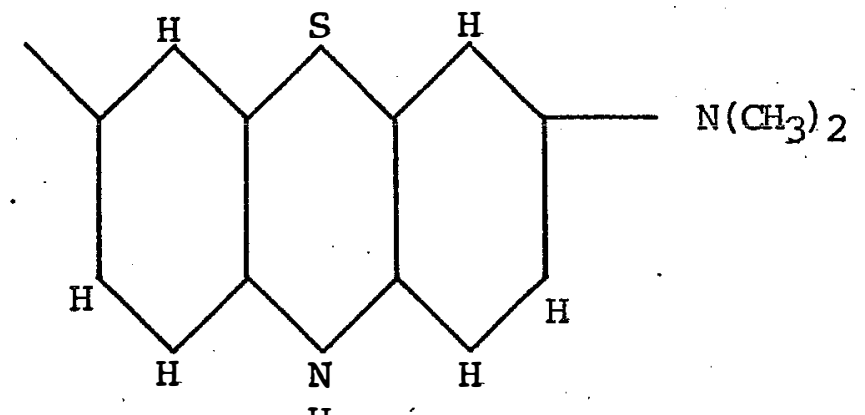

(MERCK INDEX, 1960)

LEUCO AZUL DE METILENO

Segundo FOSTER et alii (1957) diferentes explicações tem sido oferecidas para o mecanismo de redução do azul de metileno durante o teste. Como o oxigênio é removido do leite através do processo respiratório das bactérias ocorre a mudança no potencial de oxi-redução. Tendo o oxigênio normalmente potencial positivo, quando esse diminui possivelmente o hidrogênio presente nos constituintes do leite e meta bólitos dạs bactérias são transferidos para o azul de metileno fazendo-o passar para a forma leuco (incolor).

Azúl de metileno+2e+2 $\mathrm{H}^{+} \rightleftharpoons>\underset{(\text { leuco forma (incolor) }}{(\text { SMITH, 1964). }}$

De acordo com o Standard Methods for the Examination of Dairy Products (A.P.H.A., 1978) a leitura dos resultados poderá ser feita após trinta minutos de incubação dos tubos a $370^{\circ}, 2^{\circ} \mathrm{C}$, de hora em hora ou até a descoloração total. Este mesmo compêndio faz a seguinte observação; "embora a redução do azul de metileno ocorra em baixos va 
lores de $\mathrm{pH}$ (>acidez) a habilidade de um microrganismo em pro duzir ácido e reduzir o corante não são necessariamente correlacionados" .

\subsubsection{Redução da rezasurina}

Rezasurina, corante vermelho escuro, recebe a denominação de Diazoresorcinol-3-isofenoxazinone 10-oxide, com a seguinte estrutura quimica.

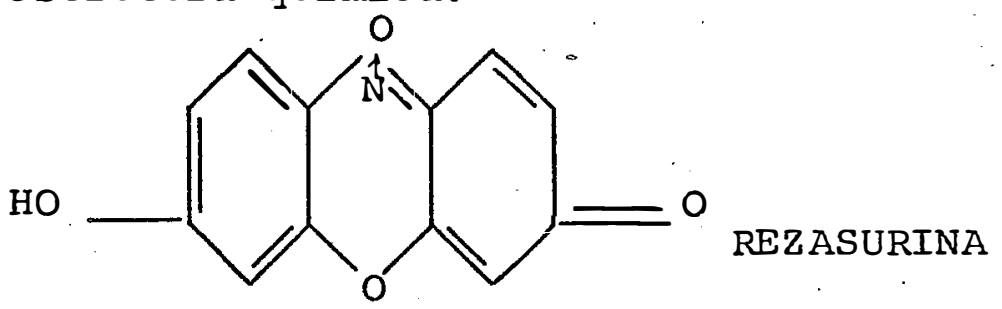

(MERCK INDEX, 1960)。

o uso da rezasurina é uma prova similar à do azul de metileno, para se medir a qualidade bacteriológica do leite, utilizando-a como indicador. Sua cor pH normal é azul. Este composto se reduz a resorufina, de coloração rosada, mudando lentamente durante o processo de redução, pas sando da cor inicial, para tonalidades de lilás até rosa. Este estágio da reação é irreversĩvel e a mudança para resorufí na produz um abaixamento no potencial de oxi-redução.

Seguindo-se, este composto se reduz a hidroresorufina, que é incolor, sendo esta última reação reversível (GOSTER et alii, 1957).

De acordo com o standard Methods for the Exa- 
mination of Dairy Products (A.P.H.A., 1978), o registro de lei tura dos resultados pode ser de dois tipos:

1. Teste de Leitura Tríplice - estabelecendo - se uma cor padrão: lilás; comparando-a com a dos tubos ao finaḷ. de três sucessivos intervalos de uma hora de incubação.

2. Teste de Leitura de U̇ma Hora - utiliza - se uma seqtência de cores, partindo-se do azul, para tonalidades.. intermediárias de lilás ațé rosa; a qualidade para classifi cação do leite, depende da cor presente ao final do tempo estipulado para o teste.

\subsection{Emprego do teste de redutase}

$$
\text { NADER FILHO, SCHOCKEN-ITURRINO, FUKUDA }
$$

realizaram um estudo comparativo entre a prova da redutase, contagem em placas e contagem leucocitária em amostras de leị te "in natura", oriundas de vacas positivas ao California Mas titis Test (CMT). Verificaram hạver uma provävel interferência dos leucócitos quando presentes no leite em nümero elevado, de modo a abreviar o tempo de redução do azul de metileno. Entretanto, esse fato não invalida a utilidade do teste de redutase na rotina do Serviço de Inspeção, uma vez que as variações observadas ocorrerạm no sentido de colocar fora dos padrões regulamentares, um produto considerado impróprio para o consumo. 
Esses mesmos autores, estudando o teste de redutase para animais negativos ao California Mastitis Test (OMT) utilizaram vários agentes etiológicos da mastite bovina, inoculados experimentalmente em amostras de leite com pequeno número de leucócitos (>100.000 leucócitos/ml). Os resultados obtidos demonstraram que a interferência de leucócitos foi considerada mínima para se colocar o produto fora dos padrões regulamentares permitida pelo Ministério da Agricultura, quan do esses estão ém pequeno número e confirmaram a eficiência do teste de redutase, aliados à rapidez, facilidade de execução e baixo custo, justificando assim sua ampla utilização a nível de estabelecimentos ịdustriais.

Para LOPES, SILVA FILHO e PORTO (1964) a prova de redutase pode apresentar limitações quanto a capacidade redutora de diferentes microrganismos, visto que, certos strains de streptococcus causadores de mastite bovina não reduzem o azul de metileno, o qual exerce uma ação inibidora so bre os mesmos. Assim sendo, se estas bactérias estiverem pre sentes no lẹte em elevado número poderá haver uma diminuição da eficácia do teste. Por outro lado, NADER et alii (1983), estudando a atividade de agentes etiológicos da mastite na re dução do azul de metileno, concluíram que a maioria dos estrep totocos tem comportamento semelhante no decorrer da prova, refutando a afirmação de Lọps et alii (1964), com relação a não redução do referido corante por strains de Streptococcus causadores da mastite bovina. 
NICHOLS e EDWARDS $\cdot(1936)$, também jā haviam demonstrado que a presença de streptococcus mastitis em leites homogenizados não afeta o tempo de redução.

$$
\text { BERMÚDEZ, BONILLA, DEL-BAGLIVI e LABORDE }
$$

preocupados com o fator higiene do leite, utilizaram entre ou tros métodos, o de redução do azul de metileno (TRAM). Os resultados foram positivamente confirmados, obtendo-se para o teste, os seguintes valores: 2,06\% das amostras tiveram um tempo de redução superior a cinco horas e 47,88\% tempo menor que meia hora, demonstrando assim a má qualidade higiênica, fato esse atribuído a falta; de conhecimentos, não utilizaçãodo resfriamento e transporte inadequado.

Para FRANKLIN (1965) o tipo è quantidade de mi crorganismos contidos no leite são fatores primordias na sua qualidade o que depende do grau de higiene praticado na ordenha, Sendo que o equipamento utilizado pode constituir-se em uma das mais importantes fontes de contaminação (SMYTHER,1960). Baseados em afirmações como estas, PEDRAZA, RO MERO e GREAVES (1978) estudaram o grau de contaminação baciteriana no leite após sua passagem pelo equipamento de ordenha mecânica, o efeito do resfriamento, o efeito do período de ar mazenagem; utilizando-se a determinação de acidez, pH, tempo de redução do azul de metileno (TRAM) e contagem em placas. Concluîram que o método de.redução do azul de metileno è de grande valor para se medir a qualidade bacteriológica do leite cru e que há uma alta correlação entre o teste de reduçãodo corante e contagem bacteriana. 
OTSUKA e NAKAE (1969) utilizaram um novo método de redução, empregando a rezasurina em papel de filtro, com o propósito de se determinar a qualidade sanitária no leite cru em comparação com a contagem em placas. Os resultados ex perimentais demonstraram uma alta correlação entre contagem em placas e o teste da rezasurina com papel de filtro, tornan do possível medir-se a constante da velocidade na reação, mudança na descoloração da forma rezasurina para resorufina no papel de filtro, indicando ser uma reação unimolecular. Os au tores concluĩram que ẹse método é bastante vantajoso dada a prẹcisão e simplicidade que são maiores do que a. forma conven cional em tubos.

DĀBBAH, MOATS, TATINI e OLSON (1969), selecionaram amostras de leite vindas de produtores distantes para a industrialização, analisando-as pelo método de contagem em placas a $32{ }^{\circ} \mathrm{C}$, teste de redução da rezasurina de uma hora (RRTlh) até a descoloração total. Concluíram que a aplicação do teste da RRTlh combinada a uma sequência de cores, demonstrou sèr a melhor, enquanțo que, os outros métodos apre sentam como único inconveniente o tempo, que é maior. Por outro lado, deve ser ressaltado que, no teste de RRTlh, para pessoas que não distingam cores intensas, torna-se difícil a identificação da seqtência de cores.

THAKRE e NAMBUDRIPAD (1962) demonstraram,que a taxa de atividade microbiológica e a marcha de deterioraçãono leite pásteurizado é mais rápida à $300 \mathrm{C}$ do que à $370 \mathrm{C}$, assim 
(SUDARSFNAM et alii, 2978), correlacionaram o tempo de redução no leite armazenado utilizando o azul de metileno, rezasurina e nitrato, concluindo que o teste de redução à $300 \mathrm{C}$ não é adequado para se medir o grau satisfatório no leite pasteurizado armazenado e que esses testes realizados segundo os padrões atuais $(370 \mathrm{C})$ são bastante eficientes na avaliação da qualidade do leite sob as mesmas condições, tenha ele grạu sa tisfatório inicial ou não.

BARKWORTH, IRWIN. e MATTICK (1942), utilizando os principais testes çomo contagem em placas, teste de reduçãọ do azul de metileno à 370C, redução do corante à 15,50C, nas diferentes estações do ano; comparou-os para com isso somar informações referentes aos métodos, concluíram que o tempo de redução é afetado pelo nūmero de baçtérias e sua atividade metabólica no período que compreende entre o tempo de retirada do leite e o da realização do teste, sendo necessária uma população inicial elevada para que se obtenha um abaixamento no potencial de oxi-redução que atenda as condições padronizadas.

WILSON (1936) demonstrou que o tempo de redução em leites que apresentèm uma contagem microbiana superior à $200.000 / \mathrm{ml}$ demoram para descolorir o corante um total de cinco horas no verão e seis horas no inverno. Enquanto um lei te com alto conteúdo bacteriano e pouca gordura, na estação do inverno, reduz o azul de metileno em cinco horas.

BARKWORTH et alii. (1942) examinaram o efeito 
da temperatura sobre o tempo de redução das amostras, relacionando principalmente ao efeito de temperaturas ambiente. JoHNS (1930) utilizando-se da técnica com azul de metileno demonstrou que a incubação prévia das amostras por dezoito horas à $12,8 \circ \mathrm{C}$ oferece uma melhor relação com a qualidade de conservação: Segundo HOY e BRAZ (1938) a temperatura de armazenagem afeta grandemente o tempo de redução sobre a habilidade do teste, rejeittando-se leites com altas contagens em placas e que o armazenamento por dezoí to horas à $21,10 \mathrm{C}$ foi muito rigoroso, enquanto que 0 tempo de exposição menos severo de doze' horas à 18, 3ọ ou dezoito horas à $15,60 \mathrm{C}$ teve praticamente $\bigcirc$ mesmo efeito. E geralmente tido que a exposição à altas temperaturas faz com que amostras de leite originalmente boas, tenha um tempo de redução menor, bem como nas estações frias do ano, o teste de redução pode igualmente substimar a população bacteriana.

De acordo com CHALMERS (1938), estudando a cor relação existente entre a diferença na taxa de crescimento pa ra as distintas espécies que se desenvolvem durante o teste de redução à $370 \mathrm{C}$ e a $150 \mathrm{C}$, visando a melhoria na qualidadedo leite, mantendo-o por um período de duas horas à temperatura de $150^{\circ} \mathrm{C}$ para posteriormente submetê-lo ao teste à $370 \mathrm{C}$, comparando-o com leite da ordenha matinal mantido por uma, se te, dezesseis e vinte e três horas nas mesmas condições. Concluiu que a incubação prévia por. um perîodo de quinze à vinte 
e quatro horas à $150 \mathrm{C}$ apresenta uma melhor correlação quando comparada no teste à $370 \mathrm{C}$; do que o leite que é examinado logo após sua produção, não sendo considerado seguro para comer cialização.

HISCOX (1932) trabalhando com leite já processado e resfriado, adicionou o corante azul de metileno à amos tra de leite mantendo-a à $150^{\circ}$, período designado como prévia incubação, submetendo-a posteriormente ao teste, considerando-se como ponto final a forma leuco (descoloração total), verificóu que não há variação no decorrer do processo independente do leite ter sido fervido ou resfriado.

Segundo BARKWORTH et alii. (1942), o conteúdo de coliformes em leite é de grande importância quando se visa qualidade, além do que a presença desses afeta o tempo de redução. Assim, para um produto mantido à $15,6 \circ \mathrm{C}$ e testado pelo azul de metileno à 350C, afetará os tipos de micror ganismos coliformes que irão proliferar, os resultados porēm indicam que o efeito não é marcante, visto que a simples presença desse grupo já diminui o tẹpo de redução.

Sabendo-se que a contagem em placas estima o número de bactérias independentemente de sua ação no leite, - tempo de redução é influenciado pelos tipos e números de microrganismos presentes antes da realização do teste (BARKWORTH et alii, 1942). 


\section{MATERIAL E METODOS}

\subsection{Material}

3.1.1. Matéria prima

o leite utilizado foi obtido do rebanho do Departamento de Zootecnia da E.S.A. "Luiz de Queiroz", sendo sempre coletado na primeira ordenha. Após a coleta, o leite era imediatamente levado para o laboratório para ser preparado.

\subsubsection{Microrganismos}

Os seguintes microrganismos foram utilizados para inoculação da matéria prima. 


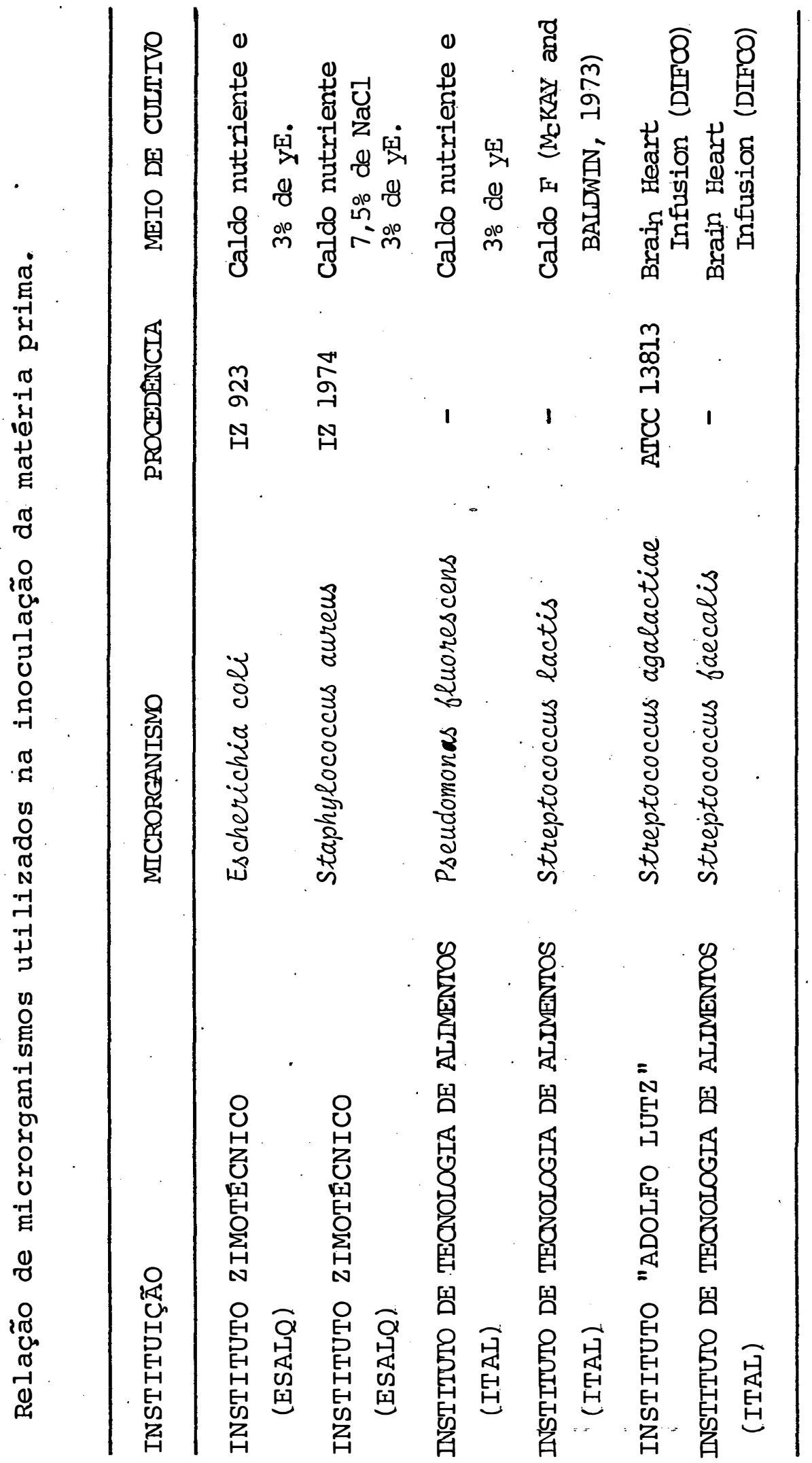




\subsubsection{Corantes}

Foram utilizadas soluções de azul de metileno a $0,0044 \%$ em pH 6,22 e rezasurina à $0,005 \%$ em pH 6,99 ; segundo indicações feitas pelo standard Methods for the Examination of Dairy Products (A.P.H.A., 1978).

\subsubsection{Soluções da Escala de McFarland}

São utilizados sete tubos de cultura contendo soluções de $\mathrm{BaCl}_{2}$ e $\mathrm{H}_{2} \mathrm{SO}_{4}$ nas proporções indicadas no método, página 33.

3.1.5. Água peptonada

Para o seu preparo 0, $1 \mathrm{~g}$ de Bacto Peptiona (DIF co) foram dissolvidas em $100 \mathrm{ml}$ de água destilada, distribuídas em tubos de cultura, esterilizados em autoclave à $1200^{\circ}$ por quinze minutos. 


\subsection{Métodos}

3.2.1. Escala de McFarland

o número de células em uma suspensão bacteriana pode ser determinado por turbidimetria, com a vantagem de se poder medir diretamente o número de células. Na escalá ce McFarland são utilizados sețe tubos preparados contendo soluçôes de $\mathrm{BaCl}_{2} \mathrm{e}_{2} \mathrm{SO}_{4}$, fechados com rolhas e que poçer: ser utilizados durante anos na comparação de suspensões bacterianas medindo-se a transmitância de luz, concluindo diretamente a densiỏade da suspensão (KIRALY et alii, 1974).

\begin{tabular}{llllll}
\hline TUBO & $\begin{array}{c}\mathrm{BaCl}_{2} \\
\mathrm{ml} \%\end{array}$ & $\begin{array}{c}\mathrm{H}_{2} \mathrm{SO}_{4} \\
\mathrm{ml} \%\end{array}$ & NO BACTERIAS $/ \mathrm{ml}$ & $\mathrm{T} \%$ & $\mathrm{~A}$ \\
\hline 1 & 0,01 & 9,99 & $30.000 .000=3 \times 10^{7}$ & 97,5 & 0,01 \\
2 & 0,05 & 9,95 & $150.000 .000=1,5 \times 10^{8}$ & 85,1 & 0,07 \\
3 & 0,1 & 9,9 & $300.000 .000=3 \times 10^{8}$ & 76,1 & 0,12 \\
4 & 0,15 & 9,85 & $450.000 .000=4,5 \times 10^{8}$ & 67,0 & 0,174 \\
5 & 0,2 & 9,8 & $600.000 .000=6 \times 10^{8}$ & 54,0 & 0,279 \\
6 & 0,3 & 9,7 & $.900 .000 .000=9 \times 10^{8}$ & 44,2 & 0,351 \\
7 & 0,4 & 9,6 & $1.200 .000 .000=1,2 \times 10^{9}$ & 31,5 & 0,50 \\
\hline
\end{tabular}

Preparou-se a escala sendo a absorbância etrans mitância das soluções medidas em esfectofotômetro moc̉elo G/20 Junior II COLEMAN, a $420 \mathrm{~nm}$ de comprimento de onda (OLSEN e. JEZESKI, 1963). . 
Tomou-se como padrão de inóculo o tubo número quatro da Escala de McFarland que representa $4.5 \times 10^{8}$ bactérias/ml, considerando-se esta população como satisfatória pạ ra o testé de redutase, uma vez que o tempo mínimo de redução estabelecido pela DIVISÃO DE INSPEÇđ̃̃ DE LEITE E DERIVADOS (DI LEI) do Ministério da Agricultura (1980) deve ser de duas horas e trinta minutos, correspondendo a uma população aproxima damente de $5 \times 10^{5}$ a $4 \times 10^{6}$ bactērịas $/ \mathrm{ml}$.

\subsubsection{Preparo do inóculo}

As culturas de microrganismos foram inoculadas assepticamente em meios de cultura segundo suas necessidades nutricionais e incubadas em estufa Retilínea FANEM modelo $315 / 3$ nas temperaturas consideradas como sendo ótimas para seu desenvolvimento, sendo para os mesófilos $32^{\circ}$ e $35^{\circ} \mathrm{C}$ por vinte e: quatro horas e psicrófilos à $210^{\circ} \mathrm{C}$ por um período de vinte e'cincó horas. Ạo final desse tempo, foram submetidas à diminuição na temperatura para aproximadamente $5^{\circ} \mathrm{C}$ a fim de paralisar o metabolismo. Posteriormente, em centrífuga angular SEVALL tipo SSl, foram centrifugadas por três vezes à $5000 \mathrm{rpm}$ por quinze minutos, sendo a massa celular lavada e ressuspensa em água peptonada esterilizada a 1\% a cada centrifugação. 
Posteriormente, homogeneizado em agitador VORTEX GENIE modelo $\mathrm{K} 55 \mathrm{G}$ à $1000 \mathrm{rpm}$ e acertadas as concentrações pelo espectofotômetro, utilizando-se como referência água destilada esterilizada, e fazendo-se as diluições necessārias para obtenção da absorbâncià e transmitância correspon dente à do tubo número quatro da Escala de McFarland.

\subsubsection{Preparo da matéria prima}

Distribuiu-se $8 \mathrm{ml}$ de leite em tubos de cultura de $15 \mathrm{~mm}$ por $160 \mathrm{~mm}$ com tampa de rosca, esterilizando-os em vapor fluente à $121^{\circ} \mathrm{C}$ ou $l$ atm por vinte minutos. Ápós a esterilização os tubos com leite tiveram suas temperatu ras ajustadas para $35^{\circ}, 300,25^{\circ}, 200,15^{\circ}, 10^{\circ}$ e $5^{\circ} \mathrm{C}$, por estarem na faixa próxima das temperaturas, às quais o leite pode chegar à usina de beneficiamento. Foram preparados três tubos para cada temperatura ensaiada.

\subsubsection{Procedimento experimental}

Em câmra asséptica, para cada triplicata de tubos com leite nas temperaturas previamente elegidas, adicionou-se $1,0 \mathrm{ml}$ do inóculo do microrganismo a ser testado no 
momento e l,0 ml de um dos corantes (azul de metileno ou rezasurina).

Fechados hermeticamente, os tubos foram homogeneizados com inversão lenta de modo a evitar a incorporação de oxigênio, seguindo-se a incubação em banho-maria modelo LAVEL à $37^{\circ} \pm 0,20^{\circ} \mathrm{C}$.

\subsubsection{Planejamento experimental e análises. estatísticas}

O tempo de redução do azul de metileno e rezasurina foi medido em minutos, até a descoloração total.

As anālises estatísticas do tempo de descolora ção dos corantes foram realizadas obedecendo ao modelo matemá tico próprio para o delineamento em blocos ao acaso, testan do-se sete temperaturas de inoculação da matéria prima, para seis diferentes culturas bacterianas e dois corantes, perfazendo uma média de dez repetiçöes para cada situação.

As regressões foram avaliadas através do coeficiente de determinação $R^{2}$, e as correlações pelo coeficien te de correlação $r$, escolhendo-se quando possível o de maior grau de significância, tendo como limite o 2 g grau.

Os esquemas de análise de variância adotados foram: 
Esquema. de análise de variância para delineamento em blocos ao acaso.

Causas da variação G. G. G.

Tratamentos

$I-1$

Blocos

B -1

Resíduo

$(I-1) \times(B-1)$

Total

$(\operatorname{IXB})-1$

I $=$ ne total de tratamentos

$\mathrm{B}=\mathrm{n}$ ? total de blocos

As comparações entre as médias dos tratamentos foram efetuadas pelo teste de Tukey, ao nível de 0,05 e $0,0.1$ de significância.

As análises dos dados foram realizadas através de computador eletrônicio IBM-1130 do Departamento de Matemátí ca e Estatística da ESALQ/USP. 


\section{RESULTADOS E DISCUSS $\widetilde{O}$}

4.1. Escherichia coli e azul de metileno (Tabelas 1 e 2).

A análise de variância mostra que não houve significância para os tratamentos, indicando que a temperatura inicial da amostra não interferiu na atividade da E. coli IZ 923 na redução do azui de metileno. Por outro lado, houve significância a nível de 0,01 entre os blocos., sugerindo que embora se tenha seguido uma homogeneidade nos experimentos, em pelo menos dois deles ocorreram variação. Isto pode ser decorrência do efeito da variação, nas características da cultura microbiana, que possa ter ocorrido durante a condução dos experimentos.

A não variação do comportamento, desse microrga nismo com a temperatura inicial da amostra, foi um fato não esperado, uma vez que, sendo um mesófilo com faixa ótima de atividade entre $250-32^{\circ} \mathrm{C}$, esperava-se um tempo maior de descoloração para as amostras a temperaturas inferiores, pois es- 
Tabela 1. Tempo de redução do corante, azul de metileno, Escherichia coli IZ 923 (minutos).

\begin{tabular}{|c|c|c|c|c|c|c|c|}
\hline \multirow{2}{*}{ Bloco No } & \multicolumn{7}{|c|}{ Temperatura da amostra $\left({ }^{\circ} \mathrm{C}\right)$} \\
\hline & 5 & 10 & 15 & 20 & 25 & 30 & 35 \\
\hline 1 & 248,3 & 254,0 & 253,3 & 258,3 & 246,3 & 250,6 & 235,3 \\
\hline 2 & 203,3 & 202,3 & 202,0 & 214,3 & 209,0 & 203,3 & 210,0 \\
\hline 3 & 253,4 & 256,0 & 260,0 & 255,0 & 248,0 & 268,6 & 231,0 \\
\hline 4 & 245,0 & 257,3 & 263,6 & 268,0 & 268,6 & 270,0 & 249,0 \\
\hline 5 & 210,6 & 211,3 & 222,0 & 239,8 & 267,9 & 227,0 & 226,4 \\
\hline 6 & 251,3 & 244,6 & 237,9 & 239,4 & 237,4 & 231,6 & 255,0 \\
\hline 7 & 223,3 & 208,0 & 224,0 & 221,6 & 210,8 & 218,3 & 223,6 \\
\hline 8 & 270,6 & 274,3 & 283,6 & 283,0 & 285,0 & 283,3 & 269,0 \\
\hline 9 & 218,6 & 225,0 & 228,3 & 230,0 & 230,3 & 233,3 & 215,3 \\
\hline 10 & $271 ; 6$ & 275,3 & 279,3 & 281,0 & 278,0 & 279,6 & 272,0 \\
\hline Média & 239,6 & 240,8 & 245,4 & 249,0 & 248,1 & 246,6 & 238,7 \\
\hline
\end{tabular}

Tabela 2. Análise de variância do teste de redutase, Escherichia coli Iz 923 e azul de metileno

\begin{tabular}{lrrrr} 
C.V. & G.L. & S.Q. & Q.M. & Teste F \\
\hline Tratamentos & 6 & 1090,22265 & 181,70377 & 2,2121 \\
Blocos & $9:$ & 36726,61332 & 4080,73481 & $49,6809 * *$ \\
Resíduo & 54 & 4435,46609 & 82,13881 & \\
\hline Total & 69 & 42252,33206 & &
\end{tabular}

** Significativo ao nível de 0,01 
sas teriam um lapso de tempo maior para atingir a temperatura ōtima para o desenvolvimento desse microrganismo.

O teste de Tukey (Apêndice - Tabelas 1 e 2 ) mos trou que não houve diferença significativa entre as médias dos tratamentos, concluindo-se que à temperatura da amostra na inoculação, não influiu diretamente no tempo de descolora ção do azul de metileno pelo microrganismo.

o coeficiente de variação a nível de experimento foi de $3,7139 \%$

Na Tabela 14 (Apêndice) encontram-se os resultados da anālise de variância para regressão, para esse microrganismo, onde observa-se significância para o componente do 2ọ grau ao nível de 0,0.1.

Colocando-se esses dados num sistema de eixos cartesianos (Gráfico 1) observa-se um aumento no tempo de redução do corante com o aumentó da temperatura da amostra na inoculação até 200 C e partir dessa, os tempos de redução de cresceram com a temperatura da amostra. Isto demonstra um comportamento. irregular desse "strain" de E. coli IZ 923, como jā discutido anteriormente.

Segundo o Standard Methods for the Examination of Dairy Products (A.P.H.A., 1978), leites contendo número equivalente de bactérias podem reduzir o corante a diferentes tempos, dependendo da fase de crescimento predominante da bactēria. Apesar de que no presente caso os experimentos foram realizados após vinte e quatro horas de incubação do mi- 


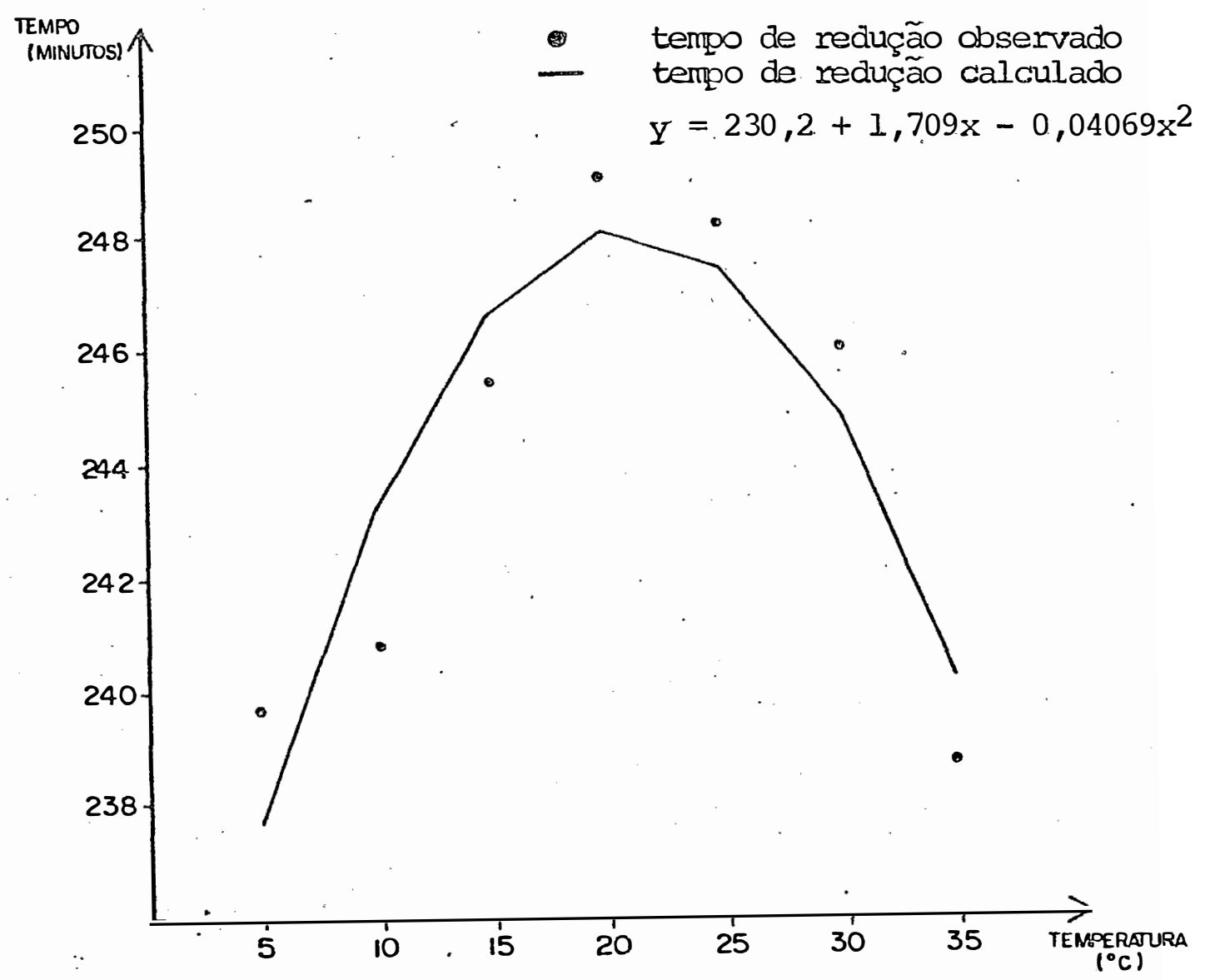

Gráfico 1. Comportamento da Escherichia coli IZ 923 e azul de metileno. 
crorganismo em meio de cultura adequado ao seu desenvolvimen-to, partindo-se do princípio de que na suspensão bacteriana utilizada, essas estivessem sempre na mesma fase de desenvolvimento:

BARKWORTH et alii (19.42) fazendo uma pré-incubação do leite a 15,6oC, e testando o tempo de redução do azul de metileno à 350C, verificaram que esta pré-incubação afetava a atividade dos coliformes presentes. Desta maneira, deduz-se que no caso do "strain" de $E$. coli IZ 923 utilizado neste experimento, quando inoculado a temperaturas inferiores de 50,100e $15{ }^{\circ} \mathrm{C}$, o tempo requerido para atingir à temperatura do método $(37 \mathrm{OC})$, tenha proporcionado uma modificação da característica metabólica do microrganismo embora, - tempo para as amostras atingirem a temperatura do experimen to tenha sido relativamente curto: 20,25 e 28 minutos respec tivamente para as temperaturas iniciais de $50,10^{\circ}$ e $150 \mathrm{C}$.

\subsection{Escherichia coli e rezasurina (Tabelas 3 e 4 )}

A análise estatística dos resultados mostram que houve significância ao nível de 0,01 para blocos e trata mentos, o que significa que pelo menos entre dois dos experimentos houve variação e as temperaturas iniciais de inocula ção influíram no comportamento do microrganismo em relação ao tempo de descoloração da rezasurina. 
Tabela 3. Tempo de redução do corante, rezasurina, Escherichia coli IZ 923 (minutos).

\begin{tabular}{cccccccc}
\hline & \multicolumn{7}{c}{ Temperatura da amostra (oC) } \\
\cline { 2 - 8 } Blocio No & 5 & 10 & 15 & 20 & 25 & 30 & 35 \\
\hline 1 & 497,0 & 500,0 & 501,0 & 503,0 & 505,0 & 506,0 & 505,0 \\
2 & 492,6 & 494,6 & 490,2 & 489,0 & 499,9 & 497,0 & 503,3 \\
3 & 494,6 & 499,6 & 497,3 & 502,6 & 505,6 & 510,0 & 518,3 \\
4 & 444,3 & 441,3 & 457,0 & 457,0 & 462,6 & 456,3 & 470,3 \\
5 & 493,0 & 498,6 & 502,6 & 503,3 & 505,3 & 511,3 & 516,0 \\
6 & 493,0 & 492,6 & 492,3 & 501,6 & 505,3 & 510,0 & 516,0 \\
7 & 493,6 & 499,3 & 505,0 & 507,6 & 514,6 & 514,0 & 516,6 \\
8 & 468,3 & 486,6 & 478,9 & 481,2 & 489,0 & 486,6 & 483,3 \\
9 & 461,0 & 464,7 & 462,3 & 469,7 & 472,3 & 477,1 & 481,0 \\
10 & 472,6 & 475,6 & 475,0 & 476,1 & 476,4 & 478,1 & 479,2 \\
\hline Média & 481,0 & 485,3 & 486,2 & 489,1 & 493,6 & 494,6 & 498,9 \\
\hline
\end{tabular}

Tabela 4. Análise de variância do teste de redutase, Escherichia coli IZ 923 e rezasurina.
C.V.
G. L。
$S \cdot Q$.
Q.M.
Teste $\mathrm{F}$

\begin{tabular}{lrrrr}
\hline Tratamentos & 6 & 2324,79687 & 387,46614 & $23,4815 * *$ \\
Blocos & 9 & 20060,65626 & 2228,96180 & $135,0814 * *$ \\
Resíduo & 54 & 891,04687 & 16,50086 & \\
\hline Total & 69 & 23276,50001 & \\
\hline
\end{tabular}

* * Significativo ao nível de 0,01 
Pelos dados das Tabelas 1 e 3 (Apêndice) constata-se que os tratamentos à $35^{\circ}, 30^{\circ}$ e $250 \mathrm{C}$ não agiram com rigor no processo de descoloração da rezasurina pela bactéria, quando comparada as temperaturas inferiores; ressaltando que a 10' e 150C, praticamente não houve diferença significativa estatisticamente entre as médias.

o coeficiente de variação a nível de experimento foi de 0,8293\%

A anālise de variância para regressão, Tabela 15 (Apêndice) demónstrou significância para o componente do 19 grau ao nível de 0.01. Assim, pelo Gráfico 2, observa-se uma correlação positiva e linear entre a temperatura da amos tra no momento da inoculação e o tempo de redução do corante. o tempo de descoloração aumentou com a elevação da temperatura inicial da amostra. Este comportamento é completamente não usual para esse microrganismo, o que pode ser decorrência de variações incontroláveis nas característi cas normais do microrganismo.

\subsection{Staphylococcus aureus e azul de metileno}

(Tabelas 5 e 6)

Os resultados mostram que houve significância ao nível de 0,01 para blocos e tratamentos, demonstrando que a temperatura de inoculação da amostra influenciou o compor- 


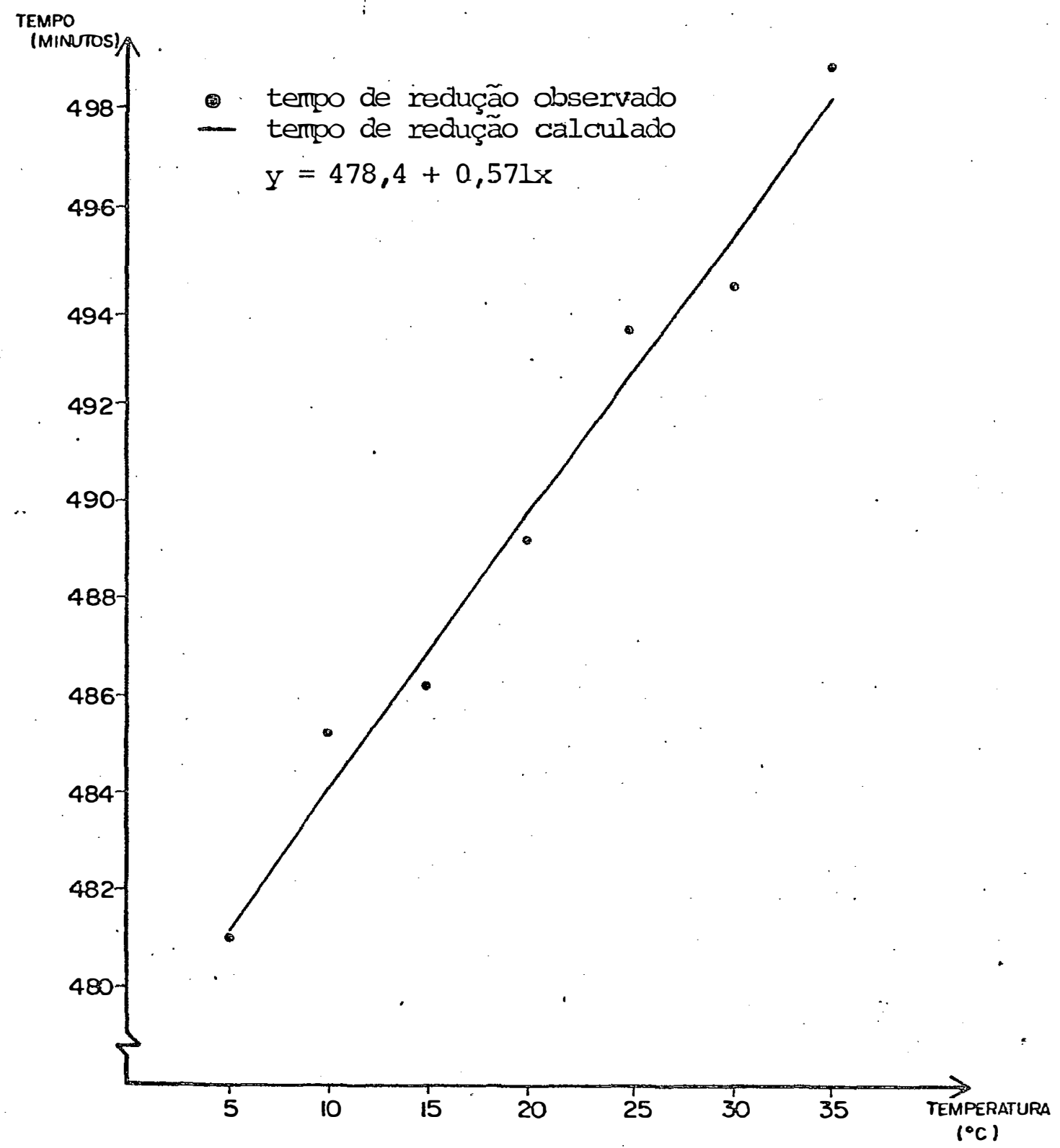

Gráfico 2. Comportamento da Escherichia coli IZ 9.2 .3 e rezasurina. 
Tabela 5. Tempo de redução do corante, azul de metileno, Staphylococcus aureus IZ 1974 (minutos).

\begin{tabular}{rccccccc}
\hline & \multicolumn{7}{c}{ Temperatura da amostra $(\circ \mathrm{C})$} \\
\cline { 2 - 8 } Bloci No & 5 & 10 & 15 & 20 & 25 & 30 & 35 \\
\cline { 2 - 9 } 1 & 132,0 & 134,6 & 119,1 & 118,8 & 116,4 & 120,0 & 118,0 \\
2 & 138,0 & 135,6 & 115,0 & 116,0 & 118,0 & 119,0 & 116,0 \\
3 & 140,0 & 137,6 & 127,6 & 129,0 & 128,3 & 130,0 & 127,6 \\
4 & 136,0 & 128,6 & 123,6 & 125,6 & 126,0 & 126,3 & 128,3 \\
5 & 138,6 & 134,6 & 128,0 & 126,3 & 124,6 & 124,6 & 123,3 \\
6 & 134,6 & 127,6 & 122,3 & 123,3 & 123,3 & 123,0 & 125,0 \\
7 & 133,0 & 131,0 & 126,0 & 126,0 & 126,6 & 127,0 & 126,0 \\
8 & 130,0 & 129,0 & 127,0 & 128,0 & 126,0 & 127,6 & 126,6 \\
9 & 130,6 & 131,0 & 128,3 & 129,6 & 124,3 & 128,0 & 125,0 \\
10 & 130,0 & 128,0 & 115,0 & 115,3 & 116,6 & 118,6 & 123,0 \\
\hline Média & 134,3 & 131,8 & 123,2 & 123,8 & 123,0 & 124,4 & 123,9 \\
\hline
\end{tabular}

Tabela 6. Análise de variância do teste de redutase, Staphyló coccus aureus IZ 1974 e azul de metileno.

C. V.

G. I.

S.Q.

Q. M.

Teste F

\begin{tabular}{lrrrr}
\hline Tratamentos & 6 & 1297,10644 & 216,18440 & $22,7771 * *$ \\
Blocos & 9 & 689,43847 & 76,60427 & $8,0710 * *$ \\
Residuo & 54 & 512,52929 & 9,49128 & \\
\hline Total & 69 & 2499,07422 & & \\
\hline
\end{tabular}

** Significativo ao nível de 0,01 
tamento do microrganismo em relação à redução do azul de metileno e que também não houve homogeneidade pelo menos entre dois dos experimentos.

De acordo com os dados da Tabela 4 (Apêndice) e os resultados obtidos do teste de Tukey, Tabela 1 (Apêndice) verificou-se que nas temperaturas de 50 e $100 \mathrm{C}$ é que o tempode redução do corante foi maior, não sendo observadas variações significativas estatisticamente para os demais tratamentos, enquadrando-se dentro dos padrões da literatura esperado para esse microrganismo em relação à metodologia.

o coeficiente de variação a nỉvel de experimen to foi de 2,4386\%. No Apêndice (Tabela 16) estão inseridos os resultados da análise de variância para regressão, apresen tando significância ao nîvel de 0,01 para tratamentos e componentes do 10 e 2\% grau. Observa-se pelo Gráfico 3, uma diminuição do tempo de redução com o aumento da temperatura iní cial da amostra até a temperatura de $25{ }^{\circ} \mathrm{C}$, e, acima dessa o tempo de redução aumentou, embora com diferenças muito pequenas.

\subsection{Staphylococcus aureus e rezasurina (Tabelas 7 e 8)}

O teste $F$ (análise de variância) mostra que houve significância ao nível de 0,01 para tratamentos e blocos. Portanto, a temperatura de inoculação da amostra in- 
48 :

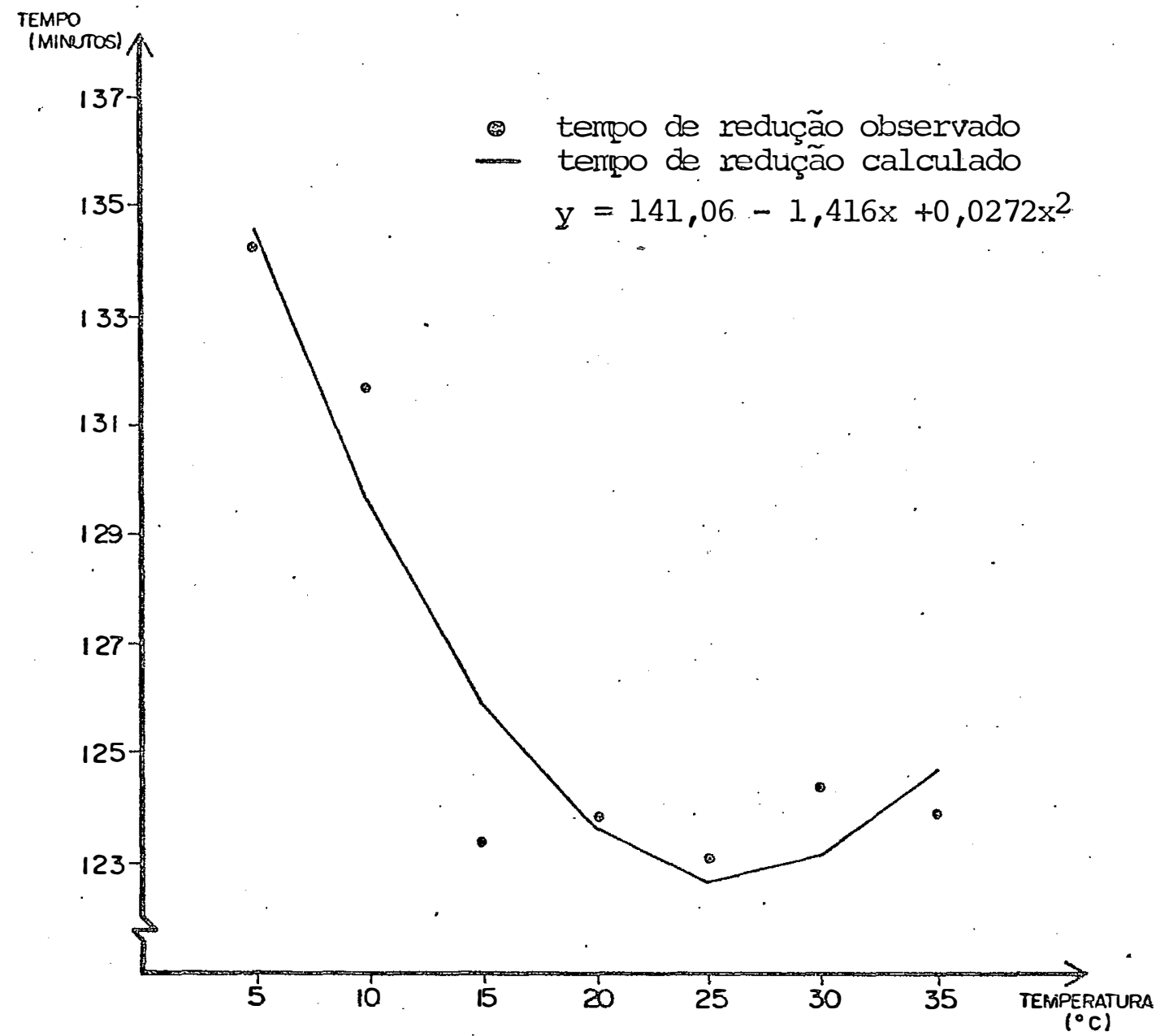

Gráfico 3. Comportamento do Staphylococcus aureus IZ 1974 e azul de metileno. 
Tabela 7. Tempo de redução do corante, rezasurina, Staphylococ cus aureus IZ 1974 (minutos)。

Temperatura da amostra (OC)

Bloco Ne

\begin{tabular}{rccccccc} 
& 5 & 10 & 15 & 20 & 25 & 30 & 35 \\
\hline 1 & 128,6 & 128,3 & 128,3 & 123,6 & 125,0 & 125,0 & 124,6 \\
2 & 127,0 & 124,3 & 122,3 & 122,0 & 121,3 & 121,3 & 123,3 \\
3 & 121,3 & 114,2 & 111,3 & 109,0 & 110,3 & 111,6 & 114,0 \\
4 & 117,3 & 117,2 & 123,0 & 119,4 & 112,3 & 118,6 & 121,3 \\
5 & 118,6 & 121,2 & 109,6 & 114,0 & 113,6 & 115,3 & 117,3 \\
6 & 124,3 & 123,6 & 126,0 & 120,0 & 120,0 & 121,2 & 119,6 \\
7 & 124,6 & 124,6 & 122,3 & 125,0 & 124,2 & 125,3 & 126,0 \\
8 & 125,3 & 125,6 & 124,6 & 124,6 & 123,0 & 123,6 & 123,3 \\
9 & 125,0 & 122,3 & 121,3 & 121,6 & 121,6 & 120,0 & 121,6 \\
10 & 125,6 & 125,3 & 124,3 & 122,6 & 123,3 & 122,0 & 124,0 \\
\hline Média & 123,8 & 122,6 & 121,3 & 120,1 & 119,5 & 120,3 & 121,6 \\
\hline
\end{tabular}

Tabela 8. Análise de variância do teste de redutase, Staphyló coccus aureus IZ 1974 e rezasurina.

\begin{tabular}{lrrrr} 
C.V. & G.L. & S.Q. & Q.M. & Teste F \\
\hline Tratamentos & 6 & 134,31591 & 22,38598 & $4,8231 * *$ \\
Blocos & 9 & 1134,56103 & 126,06233 & $27,1604 * *$ \\
Residuo & 54 & 250,63525 & 4,64139 & \\
\hline Total & 69 & 1519,51220 & & \\
\hline
\end{tabular}

* Significativo ao nível de 0,01 
fluiu no comportamento do microrganismo em relação ao tempo de redução do corante, tendo ocorrido também variação em pelo menos, dois dos experimentos.

Pelos resultados do teste de Tukey, Tabelas 1 e 5 (Apêndice) verifica-se que a variação entre as médias dos tratamentos não foi significativa, embora, como já discutido anteriormente (Tabela 8 ) as temperaturas elegidas para as amos tras no momento da inoculação afetaram de certa forma o tempo. de descoloração da rezarusina por esse microrganismo.

o coeficiente de variação a nîvel de experimen to foi de $1,7756 \%$

Os valores da análise de variância para regres são Tabela 17 (Apêndice) nos permitiram observar a significân cia para o componente do 20 grau, partindo-se dos quais se construiu $\bigcirc$ Gräfico 4, onde se verifica que esse microrganismo apresentou uma redução no tempo de descoloração da rezasurina até $250^{\circ}$ : decrescente, aumentando ligeiramente, para as temperaturas acima desta $\left(300^{\circ}\right.$ e $\left.350 \mathrm{C}\right)$.

\subsection{Streptococcus agalactiae e azul de metileno}

(Tabelas 9 e 10 )

A análise de variância (Teste F), Tabela 10, mostra que houve diferença significativa ao nível de 0,0l de probabilidade para blocos, o que demonstra que há variação en 


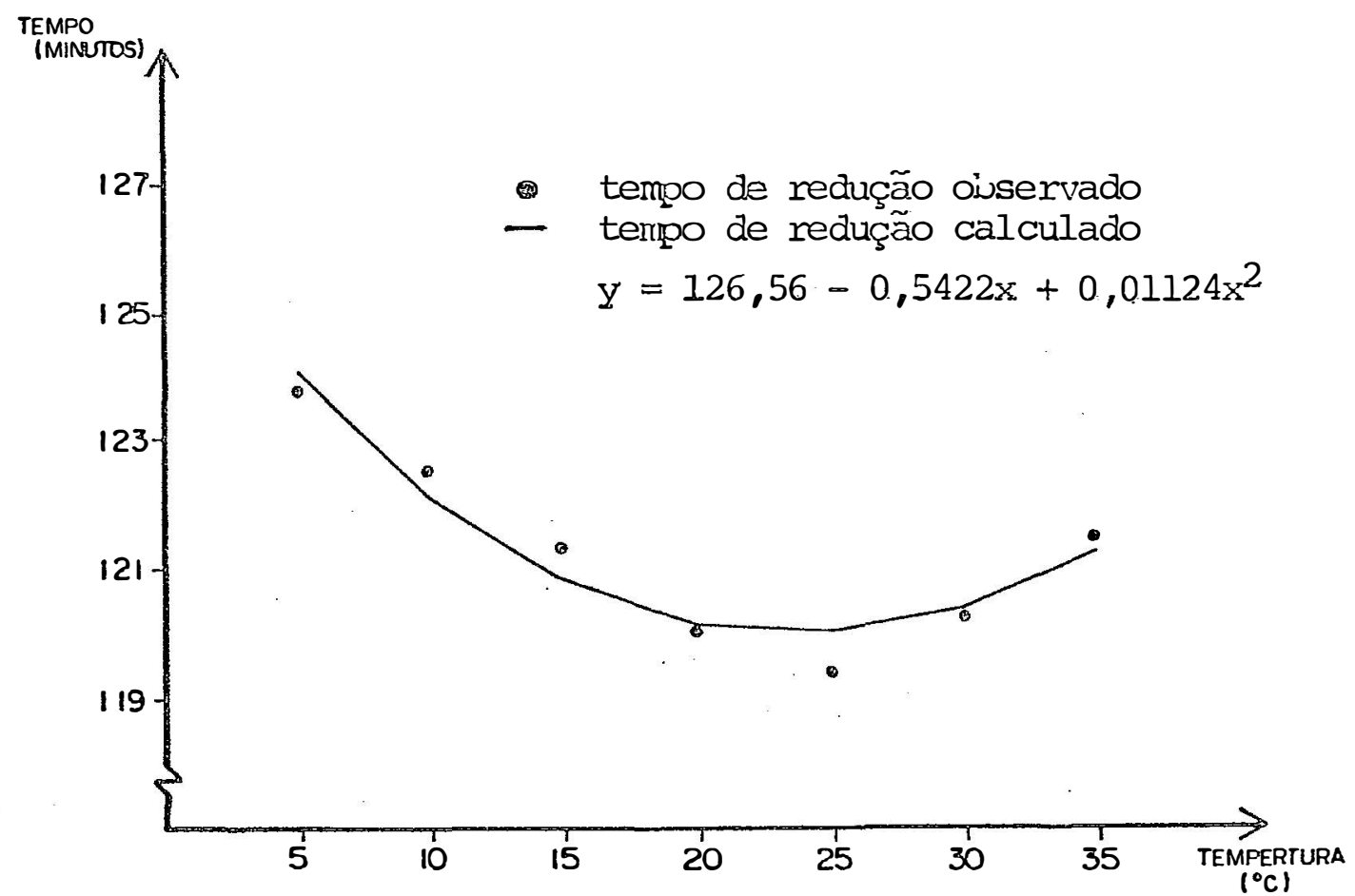

Gráfico 4. Comportamento do Staphylococcus aureus IZ 1974 e rezasurina. 
Tabela 9. Tempo de redução do corante, azul de metileno, Strep tococcus agalactiae ATCC 13813 (minutos).

Temperatura da amostra (oc)

Blocos No

$\begin{array}{lllllll}5 & 10 & 15 & 20 & 25 & 30 & 35\end{array}$

\begin{tabular}{rrrrrrrr}
\hline 1 & 60,0 & 57,2 & 50,3 & 52,3 & 53,0 & 50,3 & 53,6 \\
2 & 62,3 & 55,0 & 62,0 & 60,0 & 57,4 & 53,6 & 52,4 \\
3 & 44,6 & 47,3 & 49,6 & 50,6 & 44,3 & 45,3 & 45,6 \\
4 & 53,3 & 45,6 & 49,3 & 44,3 & 45,0 & 45,0 & 47,3 \\
5 & 54,6 & 56,6 & 56,6 & 57,1 & 58,3 & 53,0 & 53,0 \\
6 & 50,3 & 50,6 & 49,0 & 51,6 & 50,0 & 50,0 & 53,3 \\
7 & 53,6 & 57,6 & 60,0 & 57,6 & 55,3 & 52,3 & 53,8 \\
8 & 58,6 & 57,6 & 59,0 & 61,0 & 57,2 & 48,6 & 47,0 \\
9 & 58,9 & 57,3 & 58,0 & 58,3 & 60,0 & 61,6 & 64,0 \\
10 & 61,3 & 57,8 & 57,6 & 57,0 & 58,3 & 61,0 & 62,6 \\
\hline Média & 55,7 & 54,2 & 55,1 & 54,9 & 53,8 & 52,1 & 53,2 \\
\hline
\end{tabular}

Tabela 10. Análise de variância do teste de redutase, Streptọ coccus agalactiae ATCC 13813 e azul de metileno.

C. V.

G.I.

S.Q.

Q.M.

Teste F

\begin{tabular}{lrrrr}
\hline Tratamentos & 6 & 94,20751 & 15,70125 & 1,6799 \\
Blocos & 9 & 1348,98046 & 149,88671 & $16,0367 * *$ \\
Residuo & 54 & 504,70861 & 9,34645 & \\
\hline Total & 69 & 1947,89660 & & \\
\hline
\end{tabular}

** Significativo ao nível de 0,01 
tre os experimentos, apesar de se ter adotado sempre o mesmo procedimento. Por outro lado, não houve diferença significativa entre os tratamentos, sugerindo que as temperaturas estu dadas não afetaram o comportamento do microrganismo.

As Tabelas 1 e 6 (Apêndice) mostram os valores obtidos atravēs do teste de Tukey, onde não se constataram dí İerenças significativas na comparação das mëdias dos tratamentos. Entretanto, o "strain"s. agalactiae ATCC 13813 utilizado nos experimentos apresentou um tempo de redução do azul de metileno menor à medida que foram sendo aumentadas as temperaturas iniciais da amostra. Essa característica é própria do microrganismo como citado no MANUAL OF BERGEY's (1974), onde a proximidade da temperatura ótima do seu desenvolvimento resulta no aumento da sua atividade.

o coeficiente de variação a nível de experimento foi de 5,6414\%

A análise de variância para regressão Tabela 18. (Apêndice), mostra que esse microrganismo apresentou um comportamento linear. Como demonstra o Ģráfico 5, os tempos de redução do corante em relação às temperaturas iniciais da amostra, decresceram linearmente com o aumento das temperatu ras elegidas para o teste.

Segundo LOPES, SILVA FILHO e PORTO (1964) cer tos "strains" de Streptococcus causadores da mastite bovina não reduzem o azul de metileno, o qual exerce uma ação inibidora sobre os mesmos, o que poderá provocar uma diminuição da 


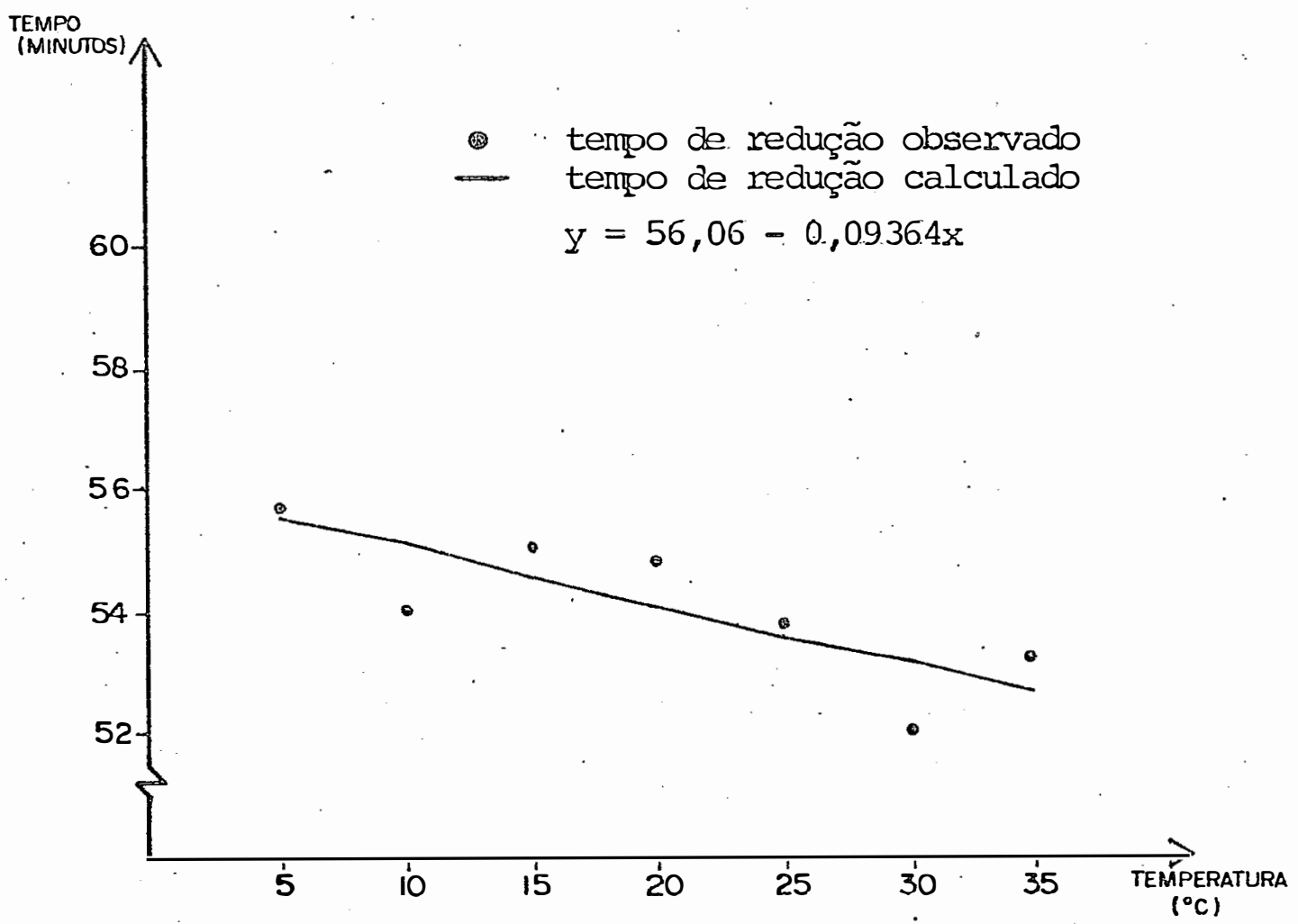

Gráfico 5. Comportamento do Streptococcus agalactiae e ATCC 13813 e azul, de metileno. 
eficācia do teste, o que está em desacordo com o comportamento do "strain" utilizado nesse trabalho. Isto pode ter ocorrido porque não houve interferência de outros fatores, uma vez que o leite utilizado para os testes foi esterelizado em vapor fluente.

4.6. Streptococcus agalactiae e rezasurina (Tabelas 1lel2)

Esse microrganismò na análise de variância demonstrou significância de 0,01 para os blocos.

No Apêndice (Tabelas 1 e 7) moṣtram os resultados obtidos para o teste de Tukey, não se verificando diferenças significativas na comparação das médias dọ tratamentos.

o coeficiente de variação a nível de experimento foi de $2,3503 \%$

Pela análise de variância para regressão Tabe la 19 (Apêndice) e como demonstra o. Gráfico 6, para esse microrganismo não houve significância em relação aos componentes estudados (10 e 20 graus), mostrando que a atividade des se microrganismo para redução da rezasurina é independente da temperatura inicial da amostra. 
Tabela 1l. Tempo de redução do corante, rezasurina, Streptococ cus agalactiae ATCC 13813 (minutos).

\begin{tabular}{rrrrrrrr}
\hline & \multicolumn{7}{c}{ Temperatura da amostra $(\mathrm{OC})$} \\
\cline { 2 - 8 } Bloco No & \multicolumn{1}{c}{5} & 10 & 15 & 20 & 25 & 30 & 35 \\
\hline 1 & 98,6 & 96,0 & 97,0 & 98,3 & 100,3 & 100,6 & 102,3 \\
2 & 99,0 & 99,0 & 100,6 & 111,0 & 104,0 & 102,6 & 104,3 \\
3 & 109,0 & 111,3 & 113,3 & 114,0 & 113,6 & 108,3 & 105,0 \\
4 & 109,6 & 111,3 & 114,6 & 113,6 & 113,3 & 109,0 & 105,3 \\
5 & 113,6 & 115,0 & 113,6 & 116,0 & 112,6 & 112,0 & 113,6 \\
7 & 115,3 & 116,0 & 112,0 & 110,0 & 112,6 & 111,0 & 112,6 \\
8 & 106,3 & 102,6 & 102,6 & 104,6 & 108,6 & 106,6 & 107,6 \\
9 & 105,6 & 103,3 & 103,6 & 104,3 & 107,3 & 106,0 & 109,0 \\
10 & 108,3 & 106,0 & 103,3 & 105,3 & 106,6 & 106,3 & 106,0 \\
\hline Média & 108,6 & 108,3 & 106,0 & 108,0 & 107,3 & 106,3 & 106,6 \\
\hline
\end{tabular}

Tabela 12. Análise de variância do teste de redutase, Streptococcus agalactial ATCC 13813 e rezasurina.

\begin{tabular}{lrrrr} 
C.V. & G.L. & \multicolumn{1}{c}{ S.Q. } & Q.M. & Teste F \\
\hline Tratamento & 6 & 38,30712 & 6,38452 & 1,0009 \\
Blocos & 9 & 1342,58300 & 149,17588 & $23,3880 * *$ \\
Resíduo & 54 & 344,42773 & 6,37829 & \\
\hline Total & 69 & 1725,31787 & & \\
\hline
\end{tabular}

** Significativo ao nível de 0,01: 
57.

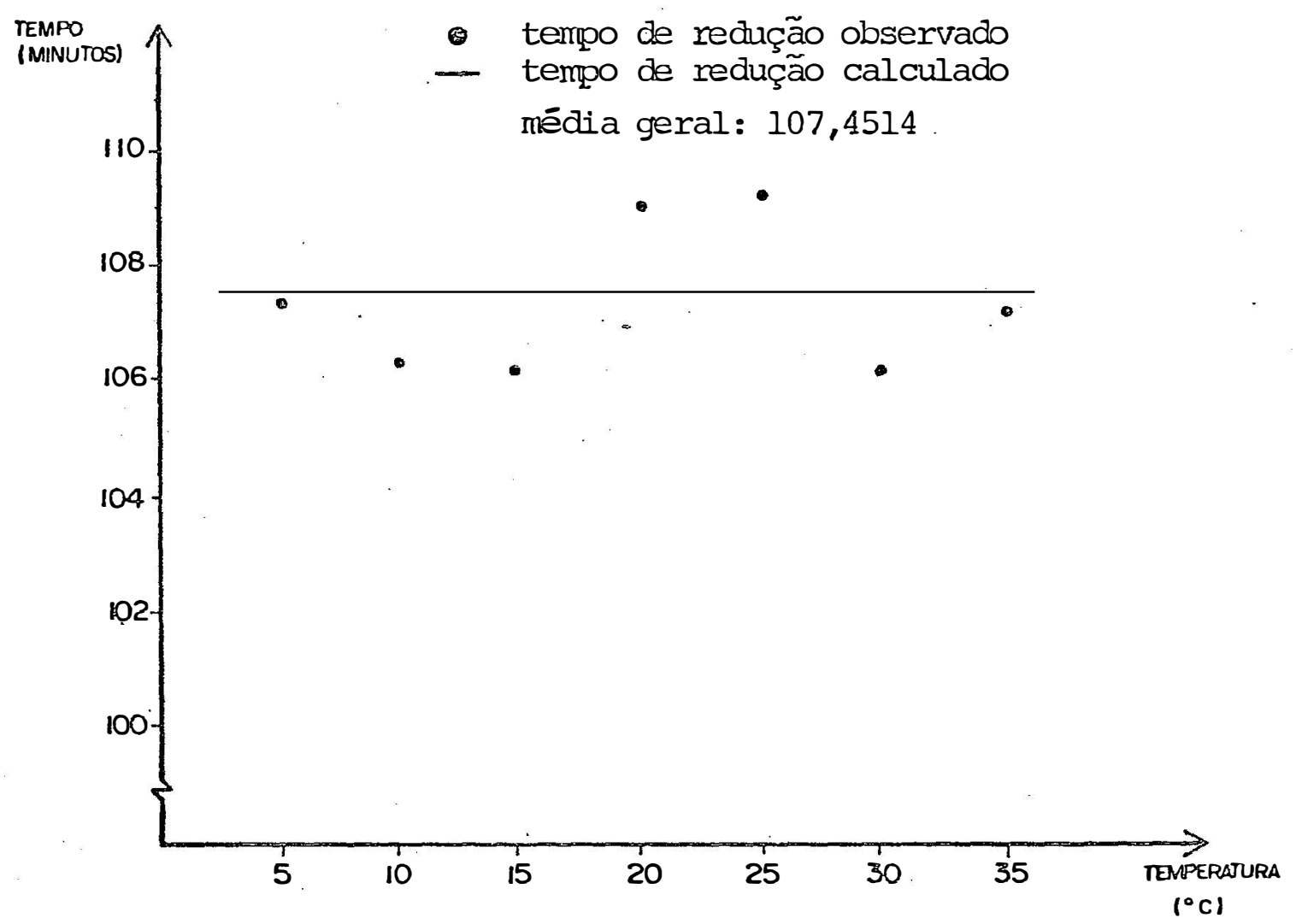

Gráfico 6. Comportamento do Streptococcus agalactiae e, ATCC 13813 e rezasurina. 
4.7. Streptococcus faecalis e azul de metileno (Tabelas 13 e 14).

Os resultados da análise de variância demonstram significância de 0,01 para tratamentos e blocos. Isto Implica que pelo menos dois experimentos diferiram, assim como, a temperatura da amostra no momento da inoculação do microrganismo afetou seu comportamento no processo de descoloração do azul de metileno.

No Apêndice (Tabelas 1 e 8 ) se observa pelas médias que, para as temperaturas de inoculação inferiores, pra ticamente não houve variação quanto ao tempo de descoloração pelo microrganismo, quando comparadas com às duas mais elevadas $\left(30^{\circ}\right.$ e $\left.35 \circ \mathrm{C}\right)$, embora tenha havido significância estatística entre os tratamentos a $30^{\circ}$ e $35 \circ \mathrm{C}$.

o coeficiente de variação a nível de experimen to foi de $7,3989 \%$

A análise de variância para regressão, Tabela 20 (apêndice) demonstrou que houve significância ao nível de 0,01 para tratamentos e componente de 10 e $2 \%$ grau, verificando-se pelo Gráfico 7, que o tempo de redução do corante foi praticamente constante até a temperatura de $150^{\circ}$, apre sentando uma diminuição à medida que a temperatura inicial da amostra foi se elevando e aproximando da faixa favorável ao desenvolvimento desse microrganismo. 
Tabela 13. Tempo de redução do corante, azul de metileno, Strep tococcus faecalis ITAL (minutos).

\begin{tabular}{cccccccc} 
Bloco No & \multicolumn{7}{c}{ Temperatura da amostra (OC) } \\
\cline { 2 - 7 } & 5 & 10 & 15 & 20 & 25 & 30 & 35 \\
\hline 1 & 19,0 & 17,0 & 16,3 & 16,0 & 14,0 & 13,0 & 10,0 \\
2 & 19,3 & 20,0 & 19,3 & 19,6 & 19,0 & 16,6 & 12,0 \\
3 & 18,0 & 16,6 & 17,6 & 16,0 & 15,0 & 12,6 & 13,3 \\
4 & 19,0 & 16,6 & 18,0 & 18,0 & 18,0 & 16,3 & 15,3 \\
5 & 19,3 & 19,6 & 18,3 & 18,3 & 18,3 & 17,0 & 18,3 \\
6 & 21,3 & 18,6 & 17,6 & 19,0 & 18,0 & 18,3 & 17,3 \\
7 & 19,0 & 16,3 & 18,3 & 19,3 & 18,3 & 16,6 & 13,0 \\
8 & 18,0 & 16,0 & 17,6 & 18,6 & 17,6 & 18,0 & 16,0 \\
9 & 19,0 & 16,3 & 18,3 & 19,3 & 18,3 & 16,6 & 13,0 \\
10 & 18,0 & 16,0 & 17,6 & 18,6 & 17,6 & 18,0 & 16,0 \\
\hline Média & 18,9 & 17,2 & 17,8 & 18,2 & 17,4 & 16,2 & 14,4 \\
\hline
\end{tabular}

Tabela 14. Análise de variância do teste de redutase, Streptococcus faecalis ITAL e azul de metileno.

\begin{tabular}{lrrrr} 
C.V. & G.L. & \multicolumn{1}{c}{ S.Q. } & Q.M. & Teste F \\
\hline Tratamento & 6 & 134,12992 & 22,35498 & 13,7618 ** \\
Blocos & 9 & 79,88542 & 8,87615 & 5,4642 ** \\
Resíduo & 54 & 87,71856 & 1,62441 & \\
\hline Total & 69 & 301,73391 & & \\
\hline
\end{tabular}

** Significativo ao nível de 0,01 
60.

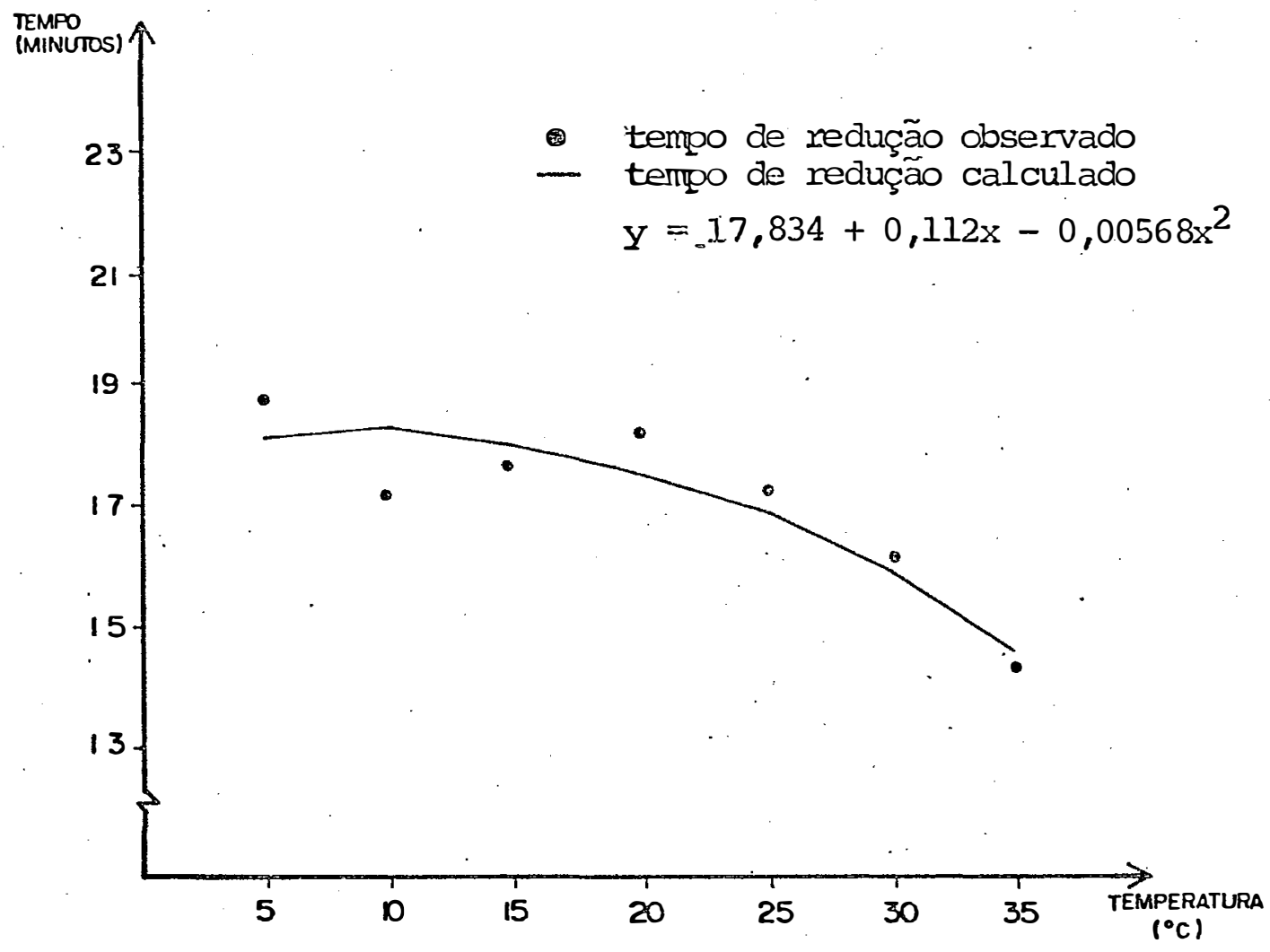

Gráfico 7. Comportamento do Streptococcus baecalis ITAL e azul de metileno. 
4.8. Streptococcus faecalis e rezasurina (Tabelas 15 e 16)

Os resultados da análise de variância (Tabela 16) mostram significância ao nível de 0,01 para blocos, o mesmo não ocorrendo para os tratamentos, sugerindo que a temperatura inicial da amostra não interferiu no comportamento do microrganismo, embora tenha havido variação entre os experinentos.

De acordo com o Apêndice (Tabelas 1 e 9), não se verificaram diferenças significativas entre as médias dos tratamentos.

O coeficiente de variação a nîvel de experimento foi de 2,1319\%.

Na Tabela 21 (Apêncide) são apresentados os resultados da análise de variância para regressão, onde se verífica não ter ocorrịdo significância nos comportamentos es tudados, como mostra também o Gráfico 8, onde o valor médio geral dos experimentos $(55,3285$ minutos) é indicativo de que a temperatura inicial de inoculação da amostra realmente não interferiu no processo de redução do corante por esse microrganismo, ou seja, o tempo de redução da rezasurina pelo S. faecalis ITAL, foi independente da temperatura inicial da amostra no momento da inoculação. 
Tabela 15. Tempo de redução do corante, rezasurina, Streptacoc cus faecalis ITAL (minutos).

Temperatura da amostra (óc)

Biloco Ne

$\begin{array}{lllllll}5 & 10 & 15 & 20 & 25 & 30 & 35\end{array}$

\begin{tabular}{rlllllll}
\hline 1 & 50,0 & 50,6 & 49,3 & 49,6 & 50,0 & 50,3 & 50,6 \\
2 & 51,6 & 55,3 & 56,3 & 55,0 & 54,3 & 52,3 & 51,6 \\
3 & 57,6 & 58,3 & 56,3 & 56,6 & 57,6 & 59,0 & 59,2 \\
4 & 57,6 & 58,6 & 58,6 & 58,6 & 57,6 & 58,3 & 58,6 \\
5 & 58,6 & 56,6 & 55,6 & 54,3 & 54,6 & 56,3 & 56,0 \\
6 & 58,6 & 54,3 & 55,6 & 56,0 & 55,6 & 54,6 & 56,0 \\
7 & 58,6 & 58,0 & 58,3 & 58,6 & 57,6 & 57,3 & 56,6 \\
8 & 58,6 & 57,6 & 58,6 & 58,3 & 58,6 & 57,6 & 58,6 \\
9 & 51,6 & 51,3 & 50,6 & 51,0 & 51,6 & 52,3 & 53,0 \\
10 & 55,6 & 55,3 & 53,6 & 54,6 & 50,6 & 53,0 & 54,0 \\
\hline Média & 55,8 & 55,5 & 55,2 & 55,2 & 54,8 & 55,1 & 55,4 \\
\hline
\end{tabular}

Tabela 16. Anālise de variância do teste de redutase, Strepto coccus faecalis ITAL e rezasurina.

\begin{tabular}{lrrrr}
\hline C.V. & G.L. & S.Q. & Q.M. & Teste F \\
\hline Tratamento & 6 & 6,66918 & 1,11153 & 0,7988 \\
Blocos & 9 & 536,93859 & 59,65984 & $42,8762 * *$ \\
Residuo & 54 & 75,13793 & 1,39144 & \\
\hline Total & 69 & 618,74572 & & \\
\hline
\end{tabular}

Significativo ao nível de 0,01 
63.

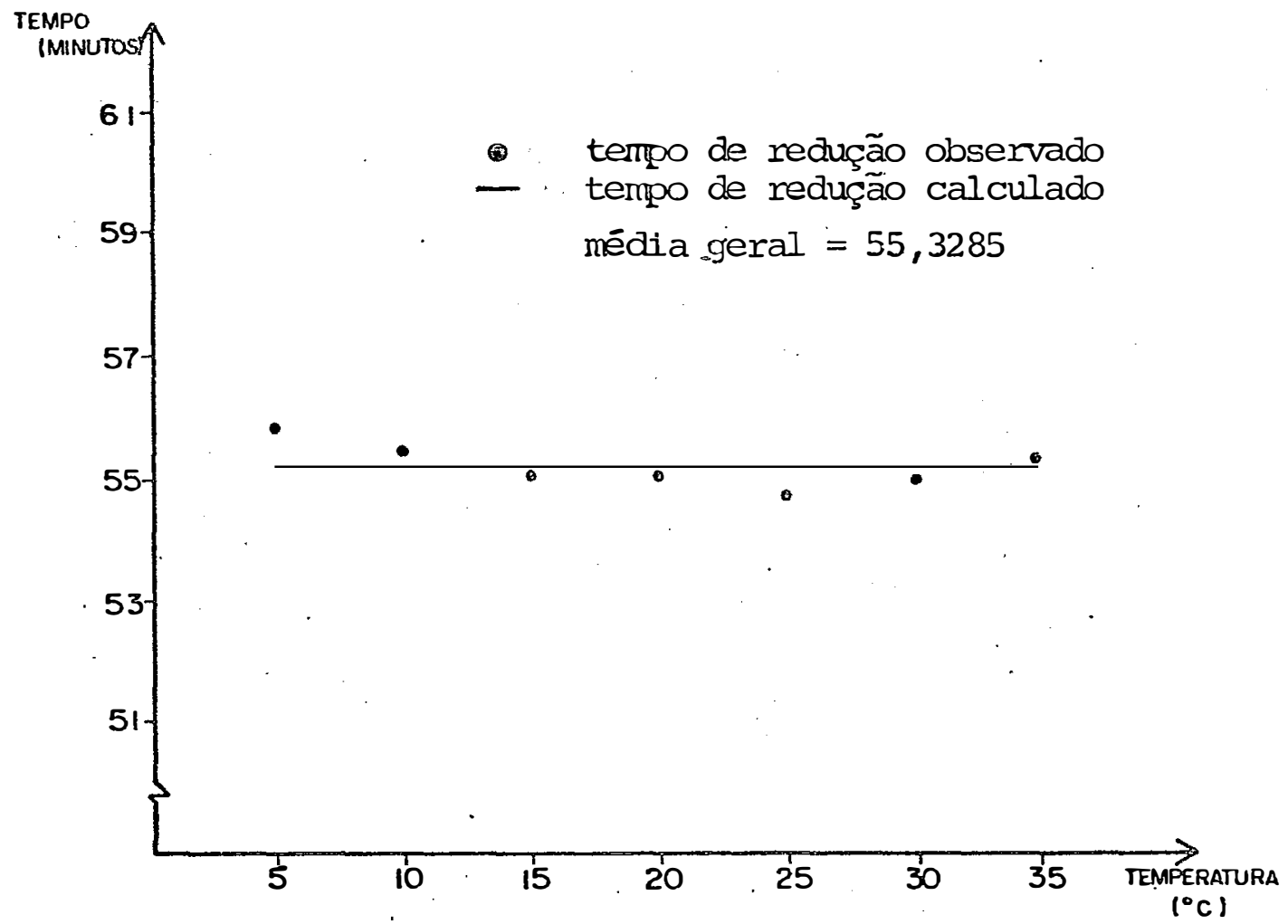

Gräfico 8. Comportamento do Streptococcus faecalis ITAL e rezasurina. 
4.9. Streptococcus Ractis e azul de metileno

(Tabelas 17 e 18)

Pela análise de variância observa-se que houve significância ao nîvel de 0,05 de probabilidade para tratamentos, sugerindo que a temperatura influiu no comportamento do microrganismo, enquanto que para blocos o nível de signi= ficância foi de 0,01 .

Pélos resultados obtidos (Tabelas 1 e 10) na comparação das médias (teste de Tukey), mostrados no apêndice verifica-se que as temperaturąs de inoculação estudadas não interferiram com rigor no tempo de descoloração do azul de me tileno por esse microrganismo, uma vez que a variação · entre as médias foi muito pequena.

o coeficiente de variação ao nível de experimento foi de $1,5127 \%$

De acordo com os dados apresentados na Tabéla 22 (Apêndice) e o Gráfico 9, verifica-se que não houve significância para os componentes testados, assim pelo valor médio geral dos experimentos $(157,0971$ minutos) se concluiu que a temperatura inicial da amostra não influenciou o comportamento redutivo do $S$. lactis ITAL em relação ao corante. 
Tabela 17. Tempo de redução do corante, azul de metileno, Strep tococcus lactis ITAL (minutos).

\begin{tabular}{cccccccc}
\hline & \multicolumn{7}{c}{ Temperatura da amostra $($ OC) } \\
\cline { 2 - 9 } Bloco No & 5 & 10 & 15 & 20 & 25 & 30 & 35 \\
\cline { 2 - 9 } 1 & 158,0 & 159,0 & 160,6 & 162,6 & 160,6 & 161,0 & 161,6 \\
2 & 167,3 & 162,6 & 164,6 & 165,6 & 165,6 & 163,0 & 161,6 \\
3 & 156,0 & 153,3 & 152,6 & 153,3 & 152,0 & 148,6 & 152,3 \\
4 & 164,3 & 158,3 & 161,3 & 154,0 & 170,6 & 158,3 & 163,3 \\
5 & 155,6 & 155,6 & 157,0 & 156,0 & 153,6 & 150,0 & 149,3 \\
7 & 158,6 & 155,6 & 152,3 & 154,6 & 156,0 & 154,6 & 153,0 \\
8 & 154,0 & 152,3 & 154,3 & 155,0 & 155,6 & 153,6 & 158,0 \\
9 & 152,6 & 152,6 & 152,0 & 153,0 & 155,3 & 154,3 & 149,6 \\
10 & 160,4 & 158,3 & 159,2 & 160,5 & 159,4 & 157,5 & 158,5 \\
\hline Média & 159,5 & 156,5 & 156,8 & 154,8 & 160,0 & 154,3 & 155,2 \\
\hline
\end{tabular}

Tabela 18. Análise de variância do teste de redutase, Streptó coccus lactis ITAL e azul de metileno.

C.V.

G.I.

S.Q.

Q.M.

Teste $\mathrm{F}$

\begin{tabular}{lrrrc}
\hline Tratamento & 6 & 92,14550 & 15,35758 & $2,7193^{*}$ \\
Blocos & 9 & 1027,13379 & 114,12597 & $20,2078 *$ \\
Residuo & 54 & 304,97070 & $5,6476.0$ & \\
\hline Total & 69 & 1424,25000 & &
\end{tabular}

* Significativo ao nível de 0,05

* *ignificativo ao nível de 0,01 
66.

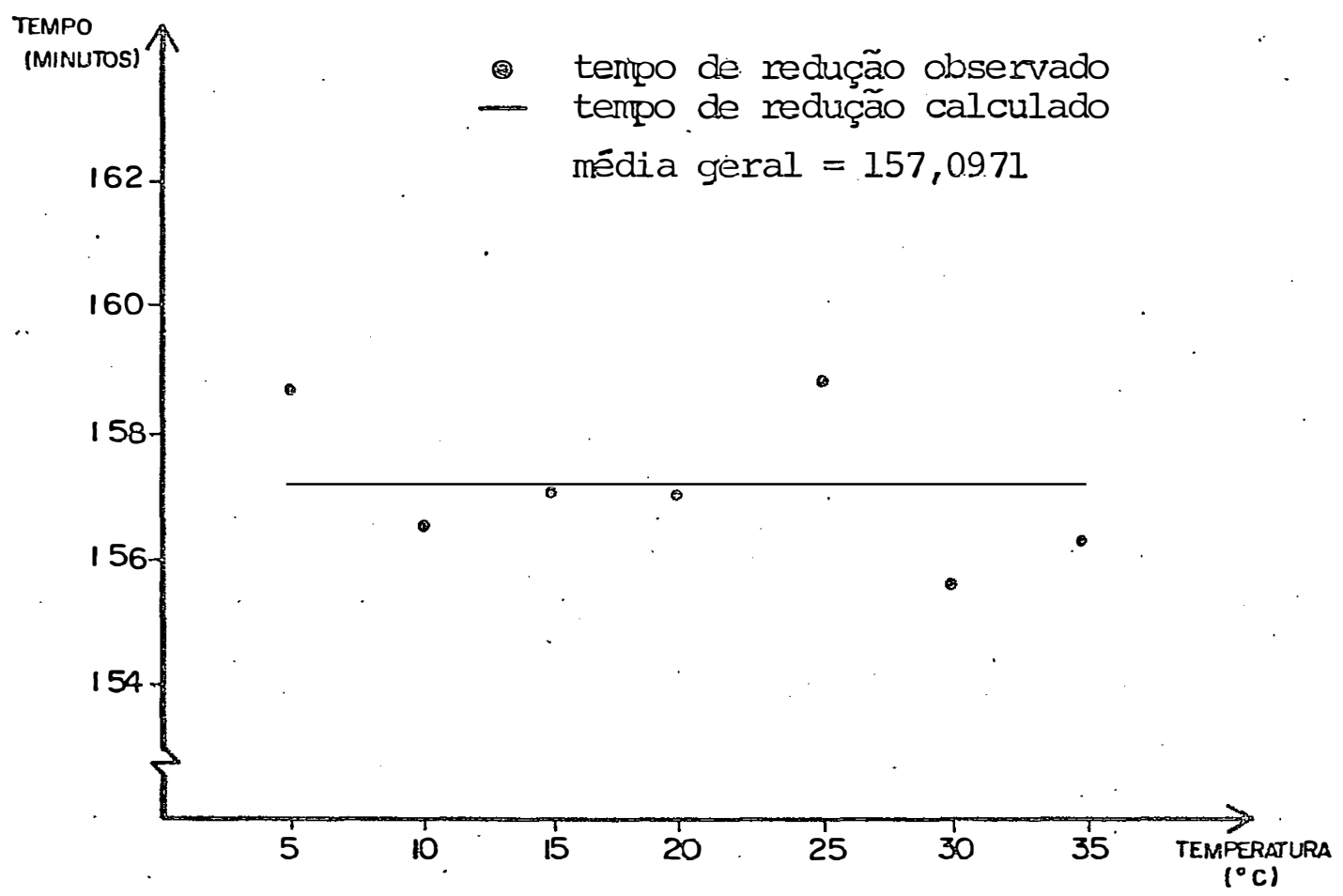

Gráfico 9. Comportamento do. Streptococcus lactis ITAI e' azul de metileno. 


\subsection{Streptococcus lactis e rezasurina}

(Tabelas 19 e 20)

A análise da variâncía. (Tabela 20) mostra que para tratamentos e blocos o teste $F$ foi significativo ao nivel de 0,01 significando que pelo menos dois experimentos se comportaram diferentemente e que a temperatura de inoculação afetou a atividade de descoloração da rezasurina pelo microrganismo.

De acordo com o Apêndice (Tabelas 1 e 1l), os resultados do teste de Tukey demonstram que somente o tratamento à $350 \mathrm{C}$ interferiu no tempo de redução da rezasurina, quan do comparado com as demais temperaturas estudadas, mesmo assim não se apresentando com tanto rigor.

o coeficiente de variação a nível de experimento foi de $0,6616 \%$

No Apêndice (Tabela 23), são mostrados os resultados da análise de variância para regressão onde se verifica significância ao nível de 0,01 para tratamentos e compo. nente do 29 grau. Isto pode ser observado no Gráfico 10, onde o maior tempo de redução ocorreu quando a amostra foi inoculada à $200 \mathrm{C}$ e os menores à 50 e $350 \mathrm{C}$, embora tenha havido para as demais temperaturas de inoculação estudadas, variações muito pequenas. 
Tabela 19. Tempo de redução do corante, rezasurina, Stueptococcus lactis ITAL (minutos).

Temperatura da amostra (óc)

Bloco No

$\begin{array}{lllllll}5 & 10 & 15 & 20 & 25 & 30 & 35\end{array}$

\begin{tabular}{rlllllll}
1 & 258,3 & 262,6 & 258,6 & 259,3 & 262,3 & 256,0 & 251,3 \\
2 & 249,3 & 250,3 & 250,6 & 251,3 & 253,6 & 255,3 & 253,6 \\
3 & 250,6 & 250,3 & 251,3 & 251,0 & 252,6 & 249,6 & 249,6 \\
4 & 248,6 & 249,3 & 249,6 & 249,6 & 251,0 & 250,3 & 248,3 \\
5 & 251,6 & 253,6 & 252,3 & 252,6 & 251,3 & 253,3 & 250,0 \\
6 & 246,3 & 245,3 & 244,0 & 246,3 & 249,6 & 249,0 & 248,6 \\
7 & 252,8 & 255,4 & 253,0 & 256,2 & 258,6 & 256,1 & 252,3 \\
8 & 249,4 & 249,5 & 250,3 & 250,2 & 251,5 & 249,6 & 248,3 \\
9 & 248,9 & 249,6 & 249,4 & 249,6 & 249,6 & 251,4 & 249,2 \\
10 & 251,8 & 253,3 & 252,2 & 254,5 & 253,9 & 253,0 & 249,6 \\
\hline Média & 250,7 & 251,9 & 251,1 & 252,0 & 253,3 & 252,3 & 250,0 \\
\hline
\end{tabular}

Tabela 20. Análise de variância do teste de redutase, Strepto coccus lactis ITAL e rezasurina.

\begin{tabular}{lrrrr}
\hline C.V. & G.L. & S.Q. & Q.M. & Teste F \\
\hline Tratamento & 6 & 73,37500 & 12,22916 & $4,4104 * *$ \\
Blocos & 9 & 635,64453 & 70,62717 & $25,4715 * *$ \\
Residuo & 54 & 149,73046 & $2,7727.8$ & \\
Total & 69 & 858,75000 & & \\
\hline
\end{tabular}

** Significativo ao nível de 0,01 


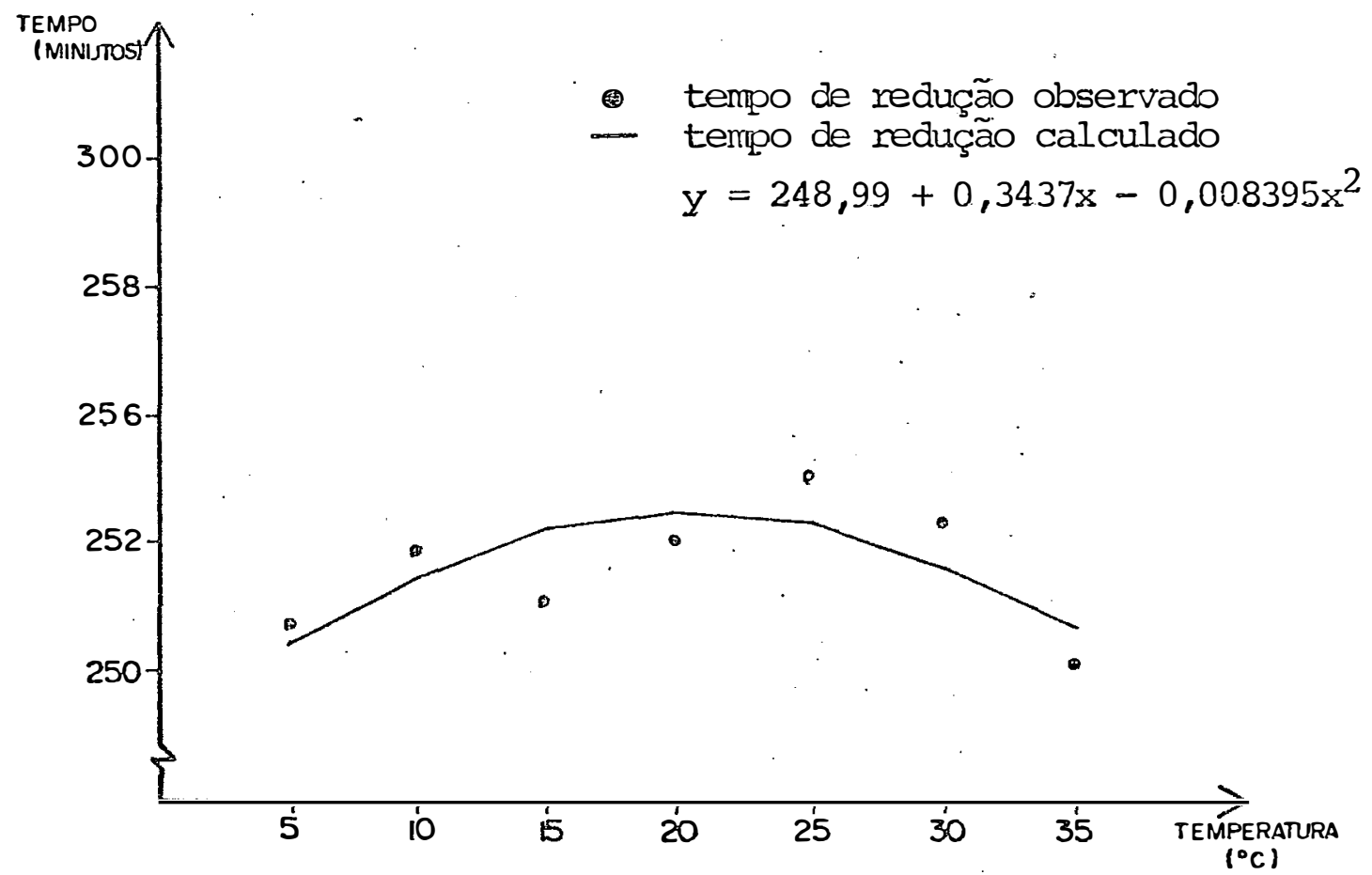

Gräfico 10. Comportamento do Streptococcus lactis ITAI e rezasurina. 


\subsection{Pseudomonas fluorescens e azul de metileno.}

(Tabelas 21 e 22)

A anālise de variânç̇a (Tabela 22), apresenta significância ao nível de 0,01 para tratamentos e blocos, demonstrando a influência da temperatura de inoculação no tem po de redução do corante por essa bactéria e uma variação entre os tratamentos.

Os resultados do teste de Tukey, apresentados no Apêndice (Tabelas 1 e 12) pode-se deduzir que embora em ordem decrescentes, as temperaturas de 5, $10^{\circ}$ e $150 \mathrm{C}$ interferiram na redução do azul de metileno quando comparada com as méđias dos experimentos à 20\%,250,300 e 350C. Tratando-se de um microrganismo psicrófilo sua tendência seria em reduzir primeiramente o corante dos experimentos efetuados nas temperaturas inferiores; a estatística nos mostra assim, um comportamento não comum desse microrganismo, isto é, tendo reduzido o coran te à forma leuco nas temperaturas maiores.

o coeficiente de variação a nível de experimento foi de $3,0886 \%$

No Apêndice (Tabela 24) a análise de variância para regressão mostra a significância de 0,01 para componente do lo grau, o que significa um comportamento linear do tem po de redução, como mostra o Gräfico ll. Já que se obteve um tempo de redução menor, as temperaturas de inoculação maiores (25․ $30^{\circ}$ e $\left.350 \mathrm{C}\right)$ e valores maiores à $5 \%, 10^{\circ}$ e $150 \mathrm{C}$ e, em se tra 
Tabela 21. Tempo de redução do corante, azul de metileno, Pseu domonas fluorescens ITAL (minutos).

Temperatura da amostra (OC)

Bloco No

$\begin{array}{lllllll}5 & 10 & 15 & 20 & 25 & 30 & 35\end{array}$

\begin{tabular}{rlllllll}
\hline 1 & 227,8 & 229,8 & 219,3 & 219,6 & 216,0 & 251,8 & 233,1 \\
2 & 189,0 & 181,4 & 183,0 & 177,9 & 180,0 & 171,8 & 177,8 \\
3 & 194,3 & 194,3 & 193,6 & 193,0 & 192,3 & 184,6 & 189,0 \\
4 & 236,4 & 238,8 & 241,6 & 226,8 & 229,8 & 237,9 & 231,8 \\
5 & 228,3 & 228,3 & 219,3 & 211,3 & 219,6 & 210,6 & 210,0 \\
6 & 220,3 & 220,6 & 217,3 & 204,0 & 204,3 & 206,3 & 209,1 \\
7 & 262,0 & 265,0 & 266,3 & 260,0 & 265,6 & 260,6 & 251,6 \\
8 & 253,6 & 253,3 & 241,9 & 240,0 & 234,0 & 231,6 & 225,0 \\
9 & 225,3 & 222,3 & 210,6 & 201,0 & 197,3 & 197,0 & 196,3 \\
10 & 210,0 & 204,6 & 199,6 & 198,6 & 202,0 & 201,0 & 209,0 \\
\hline Média & 224,6 & 223,8 & 219,2 & 213,2 & 214,0 & 215,3 & 213,2 \\
\hline
\end{tabular}

Tabela 22. Análise de variância do teste de redutase, Pseudomo nas fluorecens ITAL e azul de metileno.
C. V.
G. L。
S.Q.
Q.M.
Teste F

\begin{tabular}{lrrrr} 
Tratamento & 6 & 1474,90234 & 245,81705 & $5,4385 * *$ \\
Blocos & 9 & 36833,64067 & 4092,62673 & $90,5466 * *$ \\
Resíduo & 54 & 2440,75195 & 45,19911 & \\
\hline Total & 69 & 40749,29495 & & \\
\hline
\end{tabular}

* Significativo ao nível de 0,01 
72 .

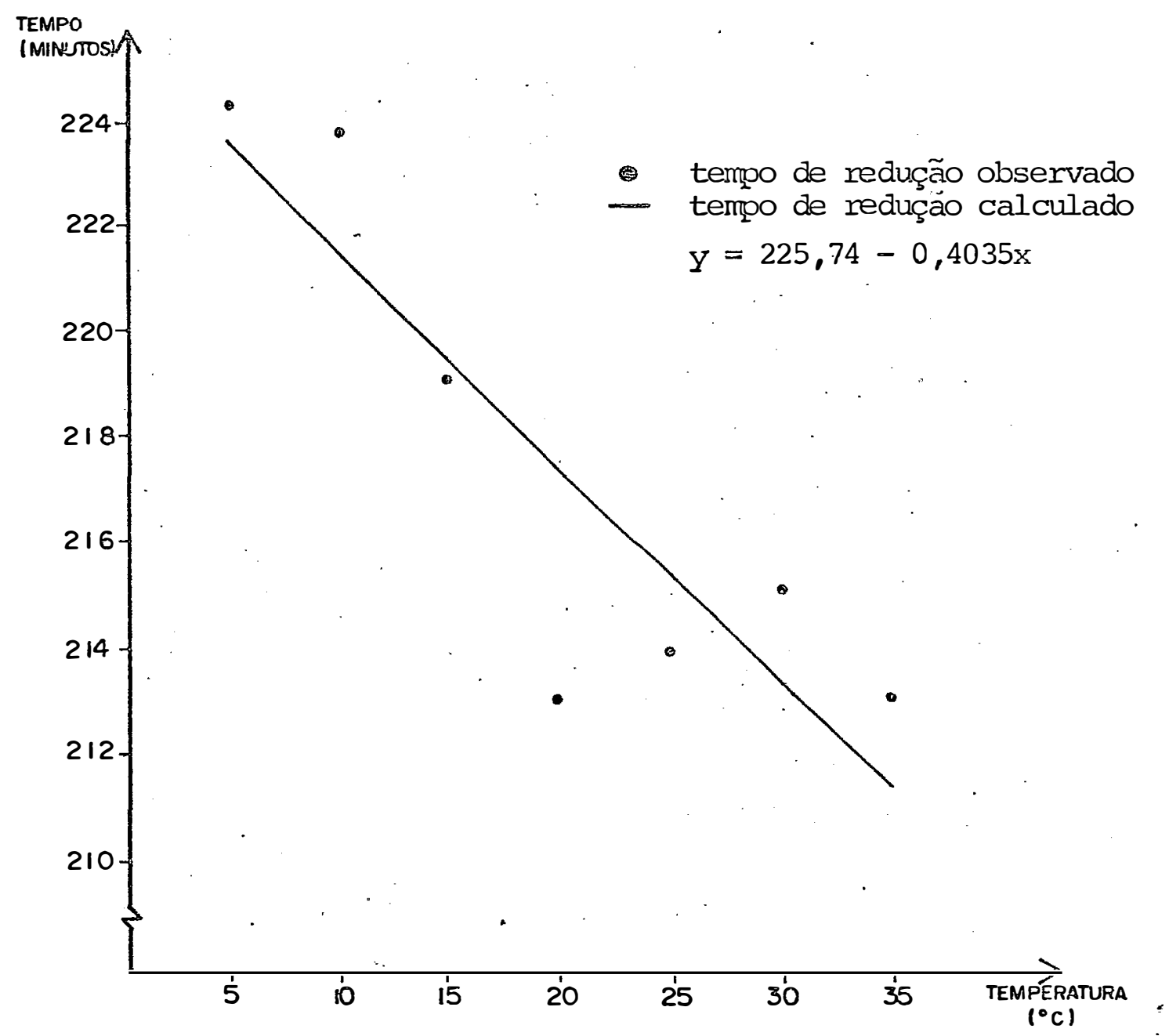

Gráfico 1l. Comportamento da Pseudomonas fluorescens ITAL e azul de metileno. 
tando de um microrganismo psicrófilo esse "strain" com o ótimo de atividade à $210 \mathrm{C}$, mas que pode se desenvolver à tempera turas inferiores, o esperado seria um tempo de redução menor às temperaturas inferiores, aumentando esse intervalo à medida que elas. se elevassem, isto sugere um comportamento não usual para o "strain" em estudo.

O tempo maior de redução do azul. de metileno apresentado por esse "strain" de P. fluorescens ITAL, está de acordo com o descrito por SCHNERR (1949), onde ele afirma que as espécies proteolíticas como a "p. fluorescens apresentam pequeno poder de redução.

\subsection{Pseudomonas fluorescens e rezasurina \\ (Tabelas 23 e 24 )}

A temperatura influiu no comportamento da bactéria com relação ao tempo de descoloração da rezasurina, vis to que a análise de variância mostrou significância ao nível de 0,01 para tratamentos e blocos (Tabela 24).

No Apêndice (Tabelas 1 e 13) inserem-se os resultados do teste de Tukey, podendo-se concluir que a variação na diferença entre as médias para as sete temperaturas testa das foram muito pequenas, exceto à $50 \mathrm{C}$, onde ocorreu um tempo de redução do corante bastante superior, colocando-se fora dos padrões normais para bactērias psicrófilas. 
Tabela 23. Tempo de redução do corante, rezasurina, Pseudomonas fluorescens ITAL (minutos).

Temperatura da: amostra (OC)

Bloco No

$\begin{array}{lllllll}5 & 10 & 15 & 20 & 25 & 30 & 35\end{array}$

\begin{tabular}{rrrrrrrr}
\hline 1 & 1052,1 & 1035,3 & 1032,6 & 1028,8 & 1017,9 & 1004,4 & 1019,9 \\
2 & 1068,6 & $10,6,2$ & 1097,2 & 1058,8 & 1095,9 & 1037,0 & 8062,8 \\
3 & 1041,6 & 983,4 & 1020,0 & 974,0 & 975,6 & 1005,1 & 995,0 \\
4 & 1032,6 & 1030,2 & 1026,9 & 997,1 & 998,8 & 1015,6 & 1001,4 \\
5 & 1031,3 & 994,4 & 977,0 & 992,4 & 989,8 & 1004,0 & 1041,2 \\
6 & 1049,3 & 984,1 & 990,8 & 985,8 & 982,1 & 984,1 & 1011,9 \\
7 & 1033,3 & 1065,1 & 1043,1 & 1027,2 & 1015,1 & 1044,6 & 1050,6 \\
8 & 1111,3 & 1080,0 & 1088,9 & 1058,1 & 1061,8 & 1066,8 & 1056,4 \\
9 & 1085,3 & 1074,2 & 1092,6 & 1071,4 & 1073,4 & 1060,4 & 1076,1 \\
10 & 1098,6 & 1105,0 & 1107,3 & 994,4 & 1015,6 & 1009,6 & 1033,3 \\
\hline Média & 1060,3 & 1043,7 & 1047,6 & 1018,7 & 1022,5 & 1023,1 & 1034,8 \\
\hline
\end{tabular}

Tabela 24. Análise de variância do teste de redutase, Pseudomo nas fluorescens ITAL e rezasurina.
C. V.
G. L.
S.Q.
$\mathrm{Q} \cdot \mathrm{M}$.
Teste F

\begin{tabular}{lrrrr} 
Tratamento & 6 & 14331,56250 & 2388,59375 & $5,9861 * *$ \\
Blocos & 9 & 63131,43753 & 7014,60416 & $1.7,5796 * *$ \\
Residuo & 54 & 21546,93752 & 399,01736 & \\
\hline Total & 69 & 99009,93759 & \\
\hline
\end{tabular}

** Significativo ao nível de 0,01 
o coeficiente de variação a nîvel de experimento foi de 1,9283\%.

Analisando-se os dados apresentados na Tabela 25 (Apêndice), se observa que houve significância para os componentes de 10 e 20 grau. O Gráfico 12, construído a par tir dos dados do componente do $2 \%$ grau, mostra que o menor tempo de redução do corante encontrado, foi para a temperatura de inoculação de $25{ }^{\circ} \mathrm{C}$, a qual se aproxima da temperatura ótima para o seu desenvolvimento, e que o tempo de redução aumentou com o aumento da temperatura de inoculação.

Na Tabela 26 (Apêndice), são mostradas as mê dias dos tempos de redução para os dois corantes estudados e as seis espécies bacterianas. Pode-se verificar que o streptococcus lactis ITAL, Streptococcus agalactiae ATCC 13813, Escherichia coli IZ 923, Staphylococcus aureus IZ 1974 e Streptococcus faecalis ITAL, tiveram um tempo de redução praticamente dobrado em relação ao corante 2 (rezasurina), enquanto que para o "strain" de Pseudomonas fluorescens ITAL, O tempo de redução da rezasurina (corante 2) foi quase cinco vezes superior àquele do corante 1 (azul de metileno), enquan to para o streptococcus faecalis ITAL a variação no tempo de redução do corante 1 para a rezasurina (corante 2) foi superior a tres vezes. Esse tipo de comportamento pelos microrganismos em rélação ao azul de metileno e a rezasurina, é prọ vavelmente decorrência da diferença do mẹcanismo de redução dos dois corantes, uma vez que na redução do azul de metileno 


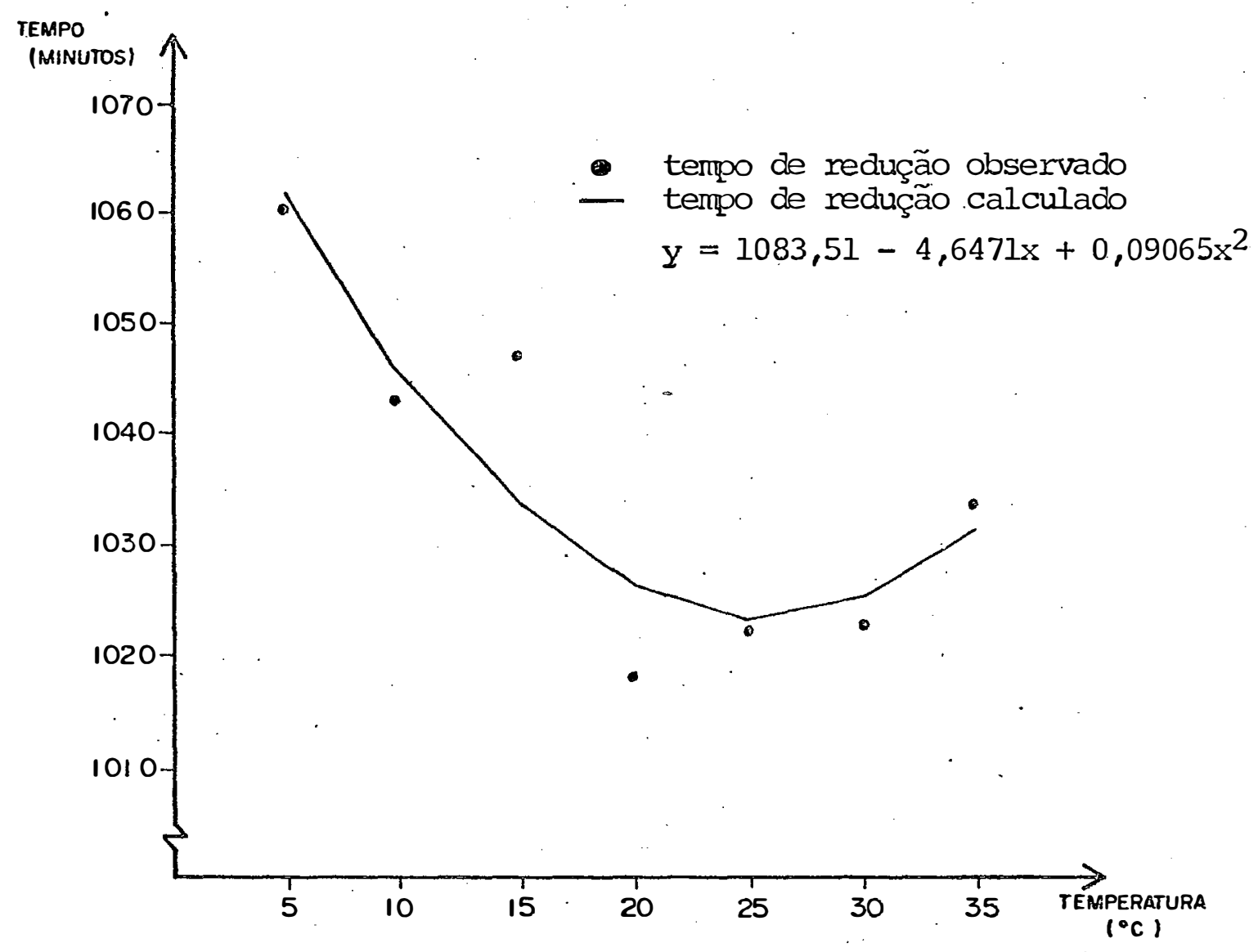

Gráfico 12. Comportamento da Pseudomonas fluorescens ITAL e rezasurina. 
há transferência do hidrogênio oriundo dos constituintes do leite e metabölitos bacterianos em uma reação reversível, resultando-se a forma leuco (incolor) è para a rezasurina duas reações, envolvem o processo, sendo primeiramente a redução da rezasurina no composto denominado resorufina através de uma reação irreversîvel e posteriormente à hidroresorufina,(for ma reversível) que é incolor (leuco). 


\section{CONCLUSÕES}

Os resultados das análises dos dados obtidos permitem as seguintes conclusões:

1. Os microrganismos ensaiados se comportaram diferen temente em relação à redução dos corantes azul de metileno e rezasurina e à temperatura inicial da amostra.

2. Para os microrganismos S. agalactiae ATCC 13813 e S. faecalis ITAL, o tempo de redução do corante re zasurina foi independente da temperatura inicial da amostra, enquanto que para $S$. lactis ITAL esse mesmo comportamento se verificou com o corante azul de metileno.

3. Das espécies investigadas o S. agalactiae ATCC 13813 foi a única que apresentou variação. linear do tempo de redução do azul de metileno com o aumento da temperatura inicial da amostra, o que é compatí vel com as características da espécie. 
4. O comportamento dos demais microrganismos na redução dos dois corantes empregados em relação à temperatura inicial da amostra foi bastante irregular não concordando com as características normais das espēcies.

5. Dadas as variações encontradas na capacidade dases pécies de microrganismos empregados, em reduzir os corantes, azul de metileno e rezasurina, os dados do presente estudo não permitem apontar nenhum dos corantes como o mais adequado para o teste de redutase, quando se varia a temperatura inicial da amostra. 


\section{IITERATURA CITADA}

AMERICAN PUBLIC HEALTH ASSOCIATION, 1972. Standard Methods for the Examination of Dairy Products. 13\% ed. American Public Health Association, Inc. Washington, D.C. $345 \mathrm{p}$.

AMERICAN PUBLIC HEALTH ASSOCIATION, 1978. Standard methods for the Examination of Dairy Products. 14: ed., Washington, D.C., p.187-195.

ANDREWS, R.H. e O.W. KAUFFMAN, 1953. The destruction of Psy chrophilic Bacteria in Milk by HTST pasteurization based on thermal death times studies. J. Dairy Sci。, 36: 570-571.

ANDREY, J. Jr. e W.C. FRAZIER, 1959. Psychrophiles in milk held two days in farm cooling tanks. J. Dairy Sci., 42: $1781-1784$.

ASHTON, T.R., 1950. Some Bacteriological Aspects of the Deterioration of Pasteurized Milk. Journal Dairy Res., London, 17: 261-287.

BARKWORTH, H.; J.O. IRWIN e A.T.R. MATTICK, 1942. The Plate Count and Methylene Blue Reduction Test Applied to milk. J. of Dairy Res..' Kent., 265-314. 
BABEL, F.J., 1953. Activity of bacteria and enzymes in raw milk held at 4,4\%C. J.Dairy Sci。, 36: 562 .

BERGDOLL, M.S., 1969. Bacterial Toxins in Food. Fd. Technol.; Champaign, 23: 530-533.

BERMUDEZ, J.; M. BONILLA; L.P. DEL-BAGLIVI.e M. LABORDE, 1976. Estudio sobre la Calidad Higiénica de la Leche Cruda Recibida en Plantas Lecheras. Revista Latinoamericana de Microbiologia, Uruguay, 18(4): 175-178.

BRASIL. Ministério da Agricultura - Secretaria de Inspeção de Produto Animal - Divisão de Leite e Derivados, 1980. Bo letim do Leite, 619: 12-14.

BRASIL. Ministério da Agricultura - Secretariā da Inspeção de Produto Animal - Divisão de Leite e Derivados, 1980. Boletim do Leite, 620: 10-12.

BRASIL. Ministério da Agricultura - Secretaria da Inspeção de Produto Animal - Divisão de Leite e Derivados, 1980. Boletim do Leite, 621: 28-30.

BRASIL. Ministērio da Agricultura - Secretaria de Inspeção de Produto Animal - SIPA - Serviço de Inspeção Federal, 1983. Boletim do Leite, 654: 1-2.

BRYAN, F.L., 1973. Diseases transmitthed by Foods (A classification and Summary). U.S. Depart. of Health, Education and Welfare, Public. Health Service, 63p.

BUCHANAN, R.E. e N.E. GIBBONS, 1974. Determinative Bacteriology Bergey's Manual. 8? ed. The Williams e Wilkins Compa ny. Baltimore. $1268 \mathrm{p}$. 
CHALMERS, C.H., 1938. The Methylene Blue Reduction Test and the Keeping Quality of Milk. J。 of Dairy Res。, Leeds, 9: $351-355$.

DABBAH, R.' et alii, 1969. "Evaluation of the Rezasurin Reduction One - Hour Test for Grading Milk Intended for Manufacturing Purposes. J. of Milk and Food Technology, Beltsville, 32(2): 44-48.

DEMETER, K.J., 1969. Lactobacteriologia, Zaragoza, España. Acribia. 33lp.

DESFLEURS, M. e M. DESFLEURS, 1977. Evaluation de la Teneur en Germes Gran Négatifs des Laits et ses Conséquences. Le lait, France, 567: 375-383.

DONNELLY, C.B. et alii, 1968. Production of enterotoxin $A$ in milk: Appl. Microbiol., 16: 917-924.

EDDY, B.P., 1960. The use of term psychrotrophic. J. Appl. Bacteriol., 23: 189-190。

ELLIKER, P.R. et alii, 1964. Psychrophilic bacteria and keeping quality of pasteurized dairy products. J. Milk Food Technol., 27: 69-75.

FOSTER, E.M. et alii, 1957. Microbiologia de la leche. Editorial Herrero S.A., México, D.F. 490 p.

FOSTER, E.M. et alii, 1957. Dairy Microbiol., New Jersey, Prentice Hall, p.128-130. 
FORD, H.F. e F.J. BABEL, 1969: Milk quality problems associated with present day marketing. J. Milk Food Technol., 22 : $141-144$.

FRANKLIN, J.G., 1965. The effect of Raw Milk Quality on the keeping Quality of Pasteurized Milk. Dairy Industry, 30 (1): $46-50$.

FRAZIER, W.C., 1967. Food Microbiol:, Mc Graw-Hill Book Com pany. New York.

FRANK, J.P. e E.H. MARTH, 1978. Survey of Soft and Semisoft Cheese for Presence of Fecal Coliforms and Serotypes of En teropathogenic Escherichia coli. J. Food protect., 41 : 198-200.

GROSSKOPF, J.C. e W.C. HARPER, 1969. Role of psychrophilic sporeformers in long-life milk: J. Dairy Sci, 52: 897.

HAMMER, B.W., 1948. Dairy Bacteriol., 3ạ ed. New York. John Williy. $598 \mathrm{p}$.

HISCOX, E.R. et alii, 1932. J. Dairy Res., 4:. I20. In: CHALMERS, C.H., 1938. The Methylene Blue Reduction Test and the Keeping Quality of Milk. Journal Dairy. Res, Leeds, 9: 351-355.

HOY \& BRAZ, 1938. Proc. SÖ. Agric. Bact Abstract. In: BARK̈WORTH, H.\& J.O. IRWIN e A.T.R. MATTICK, 1942. The Plate Count and Methylene Blue Reduction Test Applied to Milk. Journal Dairy Res., Kent., 265-314.

HOBBIGER, A. , 1962. Observations on the effect of machine milking on the higgienic quality of raw milk. Int. Dairy Congr. A., p.517-520. 
HUCKER, G.J., 1954. Low temperature organisms in frozen vege tables. Food Technol., 8: 79-108.

INTERNATIONAL DAIRY FEDERATION, 1974. Methods for Àsisessing the Bacteriological Quality of Cooled Bulk Milk from the Farm. Annual Bulletin-Document no 83: 1-19.

JAWETZ, E. et alii, 1970. Microbiologia Médica. 2th. ed., Rio de Janeiro. Ed. Guanabara. p.175-117.

JOHNS, 19.30. Sci. Agric. 11; 171. In:. . BARKWORTH, H.; J.O. IRWIN e A.T.R. MATTIC, 1942. The Plate Count and Methylene Blue Reduction Test Applied to Milk. Journal. Dairy Res., Kent., 265-314.

JUFFS, H.S. e F.J. BABEL, 1975. Inhibition of psychrotrophic bacteria by latic cultures in milk stored at low temperatụ re. J. Dairy Sci., 58: 1612-1619.

KIRĀLY, Z .; Z. KLEMENT; F. SOLYMOSY e J. VOROS, 1974. Methods in plant pathology. 2a ed. New York, Elsevier Scientific Publishing Company. 509.

LEISINGER, T. e R. MARGRAFF, 19.79. Secondary Metabolites of the Fluorescent Pseudomonads. Microbiological Reviews, 43 (3): 434-437.

LOPES, C.F.; SILVA FILHO, F.S. e PORTO, R., 1964.. Contribui ção para o estudo da redutase do leite pelo emprego da rezasurina e do azul de metileno. Bol. Ind. An., 22: 145 151.

LUCK, H., 1972. Bacteriological quality tests for bulk cooled milk. A review. Dairy Sci. Abst., 34: 101-122. 
MARTH, E.H. e W.C. FRAZIER, 1957. Bacteriology of milk held at farm bulk cooling tank temperatures III. Psyck rophiles found and their growth. J. Milk Food Technol., 20: 93-99.

MARIER, R., et alii, 1973. An out Break of. EnteropathogenicEscherichia coli Foodborne Disease traced to Imported French Cheese. Lancet., 2: 1376-1378.

MCKAY, L.L. e K.A. BALDWIN, 19.73. Induction of prophage in Streptococcus lactis $C_{2}$ by ultraviolet irradiation. Applied Microbiol., $\quad 25(4): 682-684$.

MERCK \& Co. Inc. The Merck Index, 1960. New York. Rahway.

MEHLMAN, I.J. et alii, 1974. Problems in the Recovery and identification of Enteropathogenic Escherichia coli from Food. J. Milk Food Technol., 37: 350-356.

MEHLMAN, I.J. et alii, 1976. Pathogenicity of Escherichia co li Recovered from Food. J. Ass. Off Anal. Chem.r. 59: 6780 .

MORSE, P.M. et alii, 1968. Investigation of factors contributing to the bacterial count of bulk tank milk. III. Increase in count, from cow to bulk tank and effects of refrigerated storage and preliminary incubation. J. Dairy Sci., 5l: 1192-1206.

MORITA, R.Y., 1975. Psychrophilic Bacteria. Bacteriological Reviwes. Printed. Copryright American Society of Microbiology, 39(2): 144-167. 
NADER FILHO, A.; R.P. SCHOCKEN-ITURRINO E S.P. FUKUDA, 1983. Estudo Comparativo entre a Prova de Redutase, Contagem Padrão em Placas e Contagem Leucocitária. I. Leite "In Natura" Procedente de Vacas Reagentes ao California Mastits Test (CMT). Revista do Instituto de Laticínios Cândido Tos tes, Juiz de Fora, 38(229): 37-40.

NADER FILHO, A.; R.P. SCHOCKEN-ITURRINO e S.P. FUKUDA, 1983. Estudo Comparativo entre a Prova de Redutase, Contagem Pa drão em Placas e Contagem Leucocitária. II. Leite "In Natura" Procedente de Vacas não Reagentes ao California Mastits Test (CMT). Revista do Instituto de Laticínios Cândi do Tostes, Juiz de Fora, 38(230): 19-22.

NICHOLS \& EDWARDS, 1936. J. Dairy Res., ․, 258. In: BARKWORTH, H.; J.O. IRWIN; _A.T.R. MATTICK, 1942. The Plate Count and Methylene Blue Reduction Test Applied to Milk. Journal Dairy Res., Kent., 265-314.

OLSEN, R.H. e J.J. JEZESKI, 1963. Some effects of carbon source, aeration and temperature on growth of a psychrophi lic strain of Pseudomonas fluorescens. Journal of Bacteriol., Baltimore, 86(3): 429-433.

OLIVEIRA, J.S. E C.E. PARMELLE, 1976. Rapid enumeration of psychrotrophic in raw and pasteurized milk. J. Milk Food Technol., 39: 269-272.

OTSUKA, G. e T. NAKAE, 1969. Rezasurin Test Paper Method for Determining the Sanitary Quality of Raw Milk. J. Dairy Science, 52: 2041-2044.

OVERCAST, W.W. e K. ATMARAM, 1974. The role of Bacillus ce . reus in sweet cudling of fluid milk. J. Milk Food Technol., 37: 233-236. 
PATEL, G.B. e G. BLANKENAGEL, 1972. Bacteria count of raw milk, and flavour of the milk after pasteurization and sto rage. J. Milk Food Technol., 35: 203.

PEDRAZA, C.; J.J. ROMERO e A.H. ARGREAVES, 1978. Efecto del paso de la leche por el equipo de ordeño mecánico, del enfriamento $y$ del tiempo de almanecaye, sobre su calidad bàcteriológica. Agricultura Técnica, Chile, 38: 156-160.

PELCZAR, M.; R. REID e E.C.S. CHAN, 1981. Microbiologia. Ed. MC Graw-Hill do Brasil, vol. I, 1065p.

PERROUD, M., 1983. L'Activité Oxydo-Réductrice. La Technique Laitiere, Elnor, 973: 43-44.

RENNER, E.; O. KANDLER e F. KIERMEIR, 1962. Microflora of Milk in Hand Milking Compared with Machine Milking. Dairy. Sci. Abs, 30(4): no 1328.

ROGICK, F.A. e L.H. BURGWALD, 1952. Some factors which contribute to the psychrophilic count in raw milk. J. Milk Food Technol., 15: 181-195.

RYDER, R.W. et alii, 1976. Infantile Diarrhea produced by Heat-Stable Enterotoxigenic Escherichia coli. New Eng. J. Med., 295: 849-853.

SACK, R.B., 1975. Human Diarrheal Disease Caused by Enterotoxigenic Escherichia coli. Ann. Rev. Microbiol., 28: 333 -353 .

SCHONHERR, W., 19.59. Manual Practico de Analises de Leche. Zaragoza, España. Acribia. p.83-85. 
SMYTHE, V.R., 1960. Sources of Milk Contamination of Farms. Dairy Sci. Abs, 23(3): no 3926 .

SMITH, W.H., 1964. Principles of Biochemistry. 4. ed., New York. McGraw-Hill Book Company. International stredent Ediction. 308p.

SOLBERG, R. et alii, 1974. Methods for Assessing the Bacteriological Quality of Cooled Bulk Milk from the Farm. International Dairy Federation Annual Bulletin, 83: 1-19.

SUDARSANAM, T.S.; R.N. SINHA e V.K. NAMBUDRIPAD, 1978. Relationship Between Methylene Blue, Rezasurin and Nitrato Reduction Times of Fresch and stored Pasteurised Milk. Indian Journal Dairy Science, Kamal, 31 (2): 179-180.

TAKAHASHI, I. e C.K. JOHNS, 1959. Staphylococcus aureus in Cheddar Cheese. J. Dairy Sci., 42: 1032-1037.

THOMAS, S.B.; J.M. GRIFFITHS e J.B. FOUKES, 1961. The Psych.. rophilic colony count of Milk. Dairy Engng, 78: 49.

THARKE, G.S. e V.K.N. NAMBUDRIPAD, 1962. Proc. XVI Int. Dairy Cong. C.: 921. In: T.E. SUDARSANAM; R.N. SINHA e V.K.N. NAMBUDRIPAD, 1978. Relationship Between Methylene Blue, Rezasurin and Nitrato Reduction Times of Fresch and Stored Pasteurized Milk. Indian Journal Dairy Science, Karnal, $31(2): 179-180$.

THOMAS, S.B. et alii, 1966. The significance of psychrotrophic bacteria in raw milk. Dairy Ind., 31: 27-32.

THOMAS, S.B., 1969. Methods of Assessing the Psychrotrophic Bacterial Content of Milk. Journal Applied Bacteriol., Wales, 32: 269-296. 
TROLLER, J.A., 1976. Staphylococcal growth and Enterotoxin production factors for control. J. Milk Food Technol., 39: 499-503.

UPADHYAY, J. e J.L. STOKES, 1962. Anaerobic growth of psychrophilic bacteria. Journal of Bacteriol., 23(2): 270275.

VEISSEYRE, R., 1972. Lactologia Técnica. Zaragoza, España. Acribia. $643 \mathrm{p}$.

ZACHARIAH, P. e J. LISTON, 1973. Temperature adaptability of psychrotrophic Pseudomonas. Appl. Microbiol., 26: 437438 .

WATROUS, G.H. et alii, 1971. A survey of the actual and potential bacterial keeping quality of pasteurized milk from 50. Pennsylvania dairy plants. J. Milk Food Technol., 34 : 145.

WILSON, 1936. The bacteriological grading of milk. Sep. Rep. Ser. Med. Res. Cous. Lond. no 206. In: BARKWORTH, H, J.O. IRWIN e A.T.R. MATTICK, 1942. The Plate count and Methylene Blue Reduction Test Applied to Milk. Journal_Dai ry Res., Kent., 26.5-314.

WITTER, L.D., 1961. Psychrophilic Bacteria. A. Review. J. Dairy Sci., 44: 983-10.15. 
90.

A P E N D I C E 
Tabela 1. Resultados do teste de Tukey na comparação das médias dos tratamentos incluídos nos experimentos estudados.

Microrganismo/corante

DMS
$(0,01) *(0,05) *$

E. coli/Iz 923/azul de metileno

14,8142

12,4211

E. coli Iz 923/rezasurina

6,6398

5,5672

S. aureus IZ $197 \dot{4} / a z u l$ de metileno

5,0358

4,2223

S. aureus IZ 1974/rezasurina

3,5215

2,9526

S. agalactiae ATCC 13813/azul de metileno

4,

4,1899

S. agalactiae ATCC 13813/rezasurina

4,1

3,4613

S. faecalis ITAL/azul de metileno

2,0833

1,7467

$S$. faecalis ITAL/rezasurina

1,9281

1,6166

S. lactis ITAL/azul de metileno

3,8845

3,2570

S. lactis ITAL/rezasurina

2,7218

2,2821

P. fluorescens ITAL/azul de metileno

10,9893

9,2141

P. Gluorescens. ITAL/rezasurina

32,6514

27,3769

* níveis de significância 
Tabela 2. Média dos tratamentos do experimento com E. coli IZ 923 e azul de metileno em ordem decrescente.

\begin{tabular}{crc} 
Tratamento & oC & Médias \\
\hline 4 & 20 & 249,0399 \\
5 & 25 & 248,1299 \\
6 & 30 & 246,5599 \\
3 & 15 & 245,3999 \\
2 & 10 & 240,8099 \\
1 & 5 & 239,5999 \\
7 & 35 & 238,6599
\end{tabular}

Tabela 3. Média dos tratamentos do experimento com $E$. coli IZ 923 e rezasurina em ordem decrescente.

493,5999 
Tabela 4. Média dos tratamentos do experimento com $S$. aureus IZ 19.74 e azul de metileno em ordem decrescente.

\begin{tabular}{crc} 
Tratamento & oc & Médias \\
\hline 1 & 5 & 134,2800 \\
2 & 10 & 131,7600 \\
6 & 30 & 124,4099 \\
7 & 35 & 123,8800 \\
4 & 20 & 123,7899 \\
3 & 15 & 123,1899 \\
5 & 25 & 123,0099
\end{tabular}

Tabela 5. Média dos tratamentos do experimentos com $S$. aureus IZ 1974 e rezasurina em ordem decrescente.

\begin{tabular}{ccc}
\hline Tratamento & oc & Médias \\
\hline 1 & 5 & 123,7599 \\
2 & 10 & 122,6599 \\
7 & 35 & 121,5599 \\
3 & 15 & 121,2999 \\
6 & 30 & 120,3899 \\
4 & 20 & 120,1799 \\
5 & 25 & 119,4599 \\
\hline
\end{tabular}


Tabela 6. Média dos tratamentos do experimento com $S$. agalac tiae ATCC 13813 e azul de metileno em ordem decrescente.

\begin{tabular}{ccc}
\hline Tratamento & OC & Médias \\
\hline 1 & 5 & 55,7499 \\
3 & 15 & 55,1400 \\
4 & 20 & 54,9799 \\
2 & 10 & 54,2599 \\
5 & 25 & 53,8799 \\
6 & 35 & 53,2599 \\
\hline
\end{tabular}

Tabela 7. Média dos tratamentos do experimento com S. agalac tial ATCC 13813 e rezasurina em ordem decrescente.

\begin{tabular}{crc} 
Tratamento & oC & Médias \\
\hline 5 & 25 & 108,6199 \\
4 & 20 & 108,5099 \\
1 & 5 & 107,3899 \\
7 & 35 & 107,2300 \\
2 & 10 & 106,8800 \\
6 & 30 & 106,8699 \\
3 & 15 & 106,6599
\end{tabular}


Tabela 8. Média dos tratamentos do experimento com $S$. faecalis ITAL e azul de metileno, em ordem decrescente.

Tratamento

oC . Médias

\begin{tabular}{lrl}
\hline 1 & 5 & 18,9900 \\
4 & 20 & 18,2699 \\
3 & 15 & 17,8899 \\
5 & 25 & 17,4099 \\
2 & 10 & 17,2999 \\
6 & 30 & 16,2999 \\
7 & 35 & 14,4199 \\
\hline
\end{tabular}

Tabela 9. Média dos tratamentos do experimento com $S$. faecalis ITAL e rezasurina, em ordem decrescente.

OC

Médias

1

2

7

3

4

6

5
5

10

35

15

20.

30

25
55,8399

55,5899

55,4199

55,2799

55,2599

55,0999

54,8099 
Tabela 10. Média dos tratamentos do experimento com $S$. lactis ITAL e azul de metileno, em ordem decrescente.

\begin{tabular}{crc}
\hline Tratamento & oc & Médias \\
\hline 5 & 25 & 158,8699 \\
1 & 5 & 158,6299 \\
3 & 15 & 157,0699 \\
4 & 20 & 156,9399 \\
2 & 10 & 156,4099 \\
7 & 35 & 156,2399 \\
6 & 30 & 155,5199 \\
\hline
\end{tabular}

Tabela 11. Média dos tratamentos do experimento com $S$. lactis ITAL e rezasurina, em ordem decrescente.

Tratamento

OC

Médias

\begin{tabular}{lrl}
\hline 5 & 25 & 253,3999 \\
6 & 30 & 252,3599 \\
4 & 20 & 252,0599 \\
2 & 10 & 251,9199 \\
3 & 15 & 251,1299 \\
1 & 5 & 250,7599 \\
7 & 35 & 250,0799 \\
\hline
\end{tabular}


Tabela 12. Média dos tratamentos do experimento com P. bluorescens ITAL e azul de metileno, em ordem decrescen te.

\begin{tabular}{ccc} 
Tratamento & óC & Médias \\
\hline 1 & 5 & 224,6999 \\
2 & 10 & 223,8399 \\
3 & 15 & 219,2499 \\
6 & 30 & 215,3199 \\
5 & 25 & 214,0899 \\
7 & 35 & 213,2699 \\
4 & 20 & 213,2199
\end{tabular}

Tabela 13. Média dos tratamentos do experimento com P. fluorescens ITAL e rezasurina, em ordem decrescente.

\begin{tabular}{ccc} 
Tratamento & OC & Médias \\
\hline 1 & 5 & 1060,3999 \\
3 & 15 & 1047,6399 \\
.2 & 10 & 1043,7899 \\
7 & 35 & 1034,8599 \\
6 & 30 & 1023,1599 \\
5 & 25 & 1022,5999 \\
4 & 20 & 1018,7999
\end{tabular}


93.

Tabela 14. Anālise de variância para regressão - E. coli IZ 923 e azul de metileno.

\begin{tabular}{lcccccr} 
C.V. & G.L. & S.Q. & Q.M. & F & $R^{2}$ \\
\hline Tratamento & & 6 & 1090,1 & 181,69 & 2,2120 & 100,0000 \\
Componente 19 grau & 1 & 46,495 & 46,495 & 0,5660 & 4,2649 \\
Componente 20 grau & 1 & 869,25 & 869,25 & $10,5826 * *$ & 79,7343 \\
Desyio Regr. & 4 & 174,43 & 43,609 & 0,5309 & 16,0009 \\
Resíduo & 54 & & 82,138 & & \\
\end{tabular}

** Significativo ao nivel de 0,01

Tabela 15. Análise de variância para regressão - E. coli IZ 223 e rezasurina.

\begin{tabular}{lcccccr}
\hline C.V. & & G.I. & S.Q. & Q.M. & F & $R^{2}$ \\
\hline Tratamento & & 6 & 2324,5 & 387,42 & $23,4787 * *$ & 100,0000 \\
Componente 19 grau & 1 & 2280,0 & 2280,0 & $138,1747 * *$ & 98,0848 \\
Componente 29 grau & 1 & 1,7009 & 1,7009 & 0,1030 & 0,0731 \\
Desvio Regr. & 4 & 42,826 & 10,706 & 0,6488 & $1,8423$. \\
Resíduo & 54 & & 16,500 & & \\
\hline
\end{tabular}

Significativo ao nível de 0,01 
Tabela 16. Análise de variância para regressão - S. aureus IZ 1974 e azul de metileno.

\begin{tabular}{llllll}
\hline C.V. & G.L. & S.Q. & Q.M. & $F$ & $R^{2}$
\end{tabular}

\begin{tabular}{lrrrrr}
\hline Tratariento . & 6 & 1297,0 & 216,18 & $22,7770 * *$ & 100,0000 \\
Componente 10 grau & 1 & 758,34 & 758,34 & $79,8991 * *$ & 58,4646 \\
Componente 20 grau & 1 & 387,32 & 387,32 & $40,8088 * *$ & 29,8611 \\
Desvio Regr. & 4 & 151,42 & 37,856 & $3,9885 * *$ & 11,6741 \\
Resíduo & 54 & & 9,4912 & & \\
\hline
\end{tabular}

**. Significativo ao nivel de 0,01

Tabela 17. Análise de variância para regressão - S. aureus IZ 1974 e rezasurina.

\begin{tabular}{lccccr}
\hline C.V. & G.L. & S.Q. & Q.M. & \multicolumn{1}{c}{$F$} & \multicolumn{1}{c}{$\mathrm{R}^{2}$} \\
\hline Tratamento & 6 & 134,30 & 22,384 & $4,8228^{* *}$ & 100,0000 \\
Componente 1o grau & 1 & 60,171 & 60,171 & $12,9641 * *$ & 44,8014 \\
Componente 20 grau & 1 & 66,304 & 66,304 & $14,2855^{* *}$ & 49,3679 \\
Desvio Regr. & 4 & 7,8303 & 1,9575 & 0,4217 & 5,8301 \\
Resíduo & 54 & & 4,6413 & & \\
\hline
\end{tabular}

** Significativo ao nível de 0,01 
Tabela 18. Anălise de variância para regressão - S. agalactiae ATCC13813 e azul e metileno.

\begin{tabular}{lccccr} 
C.V. & G.L. & S.Q. & Q.M. & F & $R^{2}$ \\
\hline Tratamento & 6 & 94,205 & 15,700 & 1,6798 & 100,0000 \\
Componente 10 grau & 1 & 61,382 & 61,382 & $6,5675^{*}$ & 65,1587 \\
Componente 20 grau & 1 & 44,344 & 0,44344 & 0,0474 & 0,4707 \\
Desvio Regr. & 4 & 32,378 & 8,0946 & 0,8660 & 34,3703 \\
Resíduo & 54 & & 9,3464 & &
\end{tabular}

* Significativo ao nível de 0,05

Tabela 19. Análise de variância para regressão - S. agalactiae ATCC 13813 e rezasurina.

\begin{tabular}{lccllr}
\hline C.V. & G.L. & S.Q. & Q.M. & F & \multicolumn{1}{c}{$\mathrm{R}^{2}$} \\
\hline Tratamento & 6 & 38,300 & 6,3833 & 1,0007 & 100,0000 \\
Componente 10 grau & 1 & 0,76128 & 0,76128 & 0,1193 & 1,9876 \\
Componente 2o grau & 1 & 5,4724 & 5,4724 & 0,8579 & 14,2882 \\
Desvio Regr. & 4 & 32,065 & 8,0164 & 1,2568 & 83,7224 \\
Resíduo & 54 & & 6,3782 & & \\
\hline
\end{tabular}


Tabela 20. Análise de variância para regressão - S. faecalis ITAL e azul de metileno.

\begin{tabular}{lccccc}
\hline C.V. & G.L. & S.Q. & Q.M. & $F$ & $\mathrm{R}^{2}$ \\
\hline Tratamento & 6 & 134,12 & 22,354 & $13,7618 * *$ & 100,0000 \\
Componente 10 grau & 1 & 93,612 & 93,612 & $57,6285 * *$ & 69,7927 \\
Componente 20 grau & 1 & 16,943 & 16,943 & $10,4304 * *$ & 12,6321 \\
Desvio Regr. & 4 & 23,573 & 5,8933 & $3,6279 *$ & 17,5750 \\
Resíduo & 54 & & 1,6244 & & \\
\hline
\end{tabular}

Significativo ao nível de 0,05

** Significativo ao nivel de 0,01

Tabela 21. Análise de variância para regressão - S. faecalis ITAL e rezasurina.

\begin{tabular}{lrrllr}
\hline C.V. & G.L. & S.Q. & Q.M. & $F$ & $\mathrm{R}^{2}$ \\
\hline Tratamento : & 6 & 6,6653 & 1,1108 & 0,7983 & 100,0000 \\
Componente 10 grau & 1 & 2,6228 & 2,6228 & 1,8850 & 39,3511 \\
Componente 20 grau & 1 & 2,9642 & 2,9642 & 2,1303 & 44,4732 \\
Desvio Regr. & 4 & 1,0781 & 0,26953 & 0,1937 & 16,1755 \\
Resíduo & 54 & & 1,3914 & &
\end{tabular}


Tabela 22. Análise de variância para regressão - $S$. lactis ITAL e azul de metileno.

\begin{tabular}{lccccr}
\hline C.V. & G.L. & S.Q. & Q.M. & $F$ & $\mathrm{R}^{2}$ \\
\hline Tratamento & 6 & 92,122 & 15,353 & $2,7186 *$ & 100,0000 \\
Componente 10 grau & 1 & 18,258 & 18,258 & 3,2328 & 19,8192 \\
Componente 20 grau & 1 & 0,1801 & 0,1801 & 0,0318 & 0,1955 \\
Desvio Regr. & 4 & 73,684 & 18,421 & $3,2617 *$ & 79,9852 \\
Resíduo & 54 & & 5,6476 & & \\
\hline
\end{tabular}

* Significativo ao nível de 0,05

Tabela 23. Análise de variância para regressão - S. lactis ITAL e rezasurina.

\begin{tabular}{lccccr} 
C.V. & G.L. & S.Q. & Q.M. & F & \multicolumn{1}{c}{$\mathrm{R}^{2}$} \\
\hline Tratamento & 6 & 73,312 & 12,218 & $4,4066 * *$ & 100,0000 \\
Componente 10 grau & 1 & $0,440.03$ & 0,44003 & 0,1586 & 0,6002 \\
Componente 20 grau & 1 & 37,002 & 37,002 & $13,3447 * *$ & 50,4712 \\
Desvio Regr. & 4 & 35,873 & 8,9683 & $3,2344 *$ & 48,9318 \\
Resíduo & 54 & & 2,7727 &. &
\end{tabular}

* Significativo ao nível de 0,05

** Significativo ao nível de 0,01 
Tabela 24. Análise de variância para regressão - P. fluorescens ITAL e azul de metileno.

\begin{tabular}{lrrrrrr} 
C.V. & G.L. & S.Q. & Q.M. & $F$ & $\mathrm{R}^{2}$ \\
\hline Tratamento & 6 & 1474,8 & 245,81 & $5,4384 *$ & 100,0000 \\
Componente 10 grau & 1 & 1139,6 & 1139,6 & $25,2147 * *$ & 77,2732 \\
Componente 20 grau & 1 & 162,53 & 162,53 & 3,5960 & 11,0203 \\
Desvio Regr. & 4 & 172,65 & 43,164 & 0,9549 & 11,7064 \\
Resíduo & 54 & & 45,199 & &
\end{tabular}

Significativo ao nível de 0,0.1

Tabela 25. Análise de variância para regressão - P. fluorescens IIAL e rezasurina.

\begin{tabular}{lrrrrr}
\hline C.V. & G.L. & S.Q. & Q.M. & F & $\mathrm{R}^{2}$ \\
\hline Tratamento & 6 & 14330,0 & 2388,3 & $5,9856 * *$ & 100,0000 \\
Componente 10 grau & 1 & 7295,0 & 7295,0 & $18,2825 * *$ & 50,9068 \\
Componente 2Q grau & 1 & 4314,8 & 4314,8 & $10,8136 * *$ & 30,1100 \\
Desvio Regr. & 4 & 2720,3 & 680,09 & 1,7044 & 18,9834 \\
Resíduo & 54 & & 399,01 & & \\
\end{tabular}

**. Significativo ao nível de 0,01 


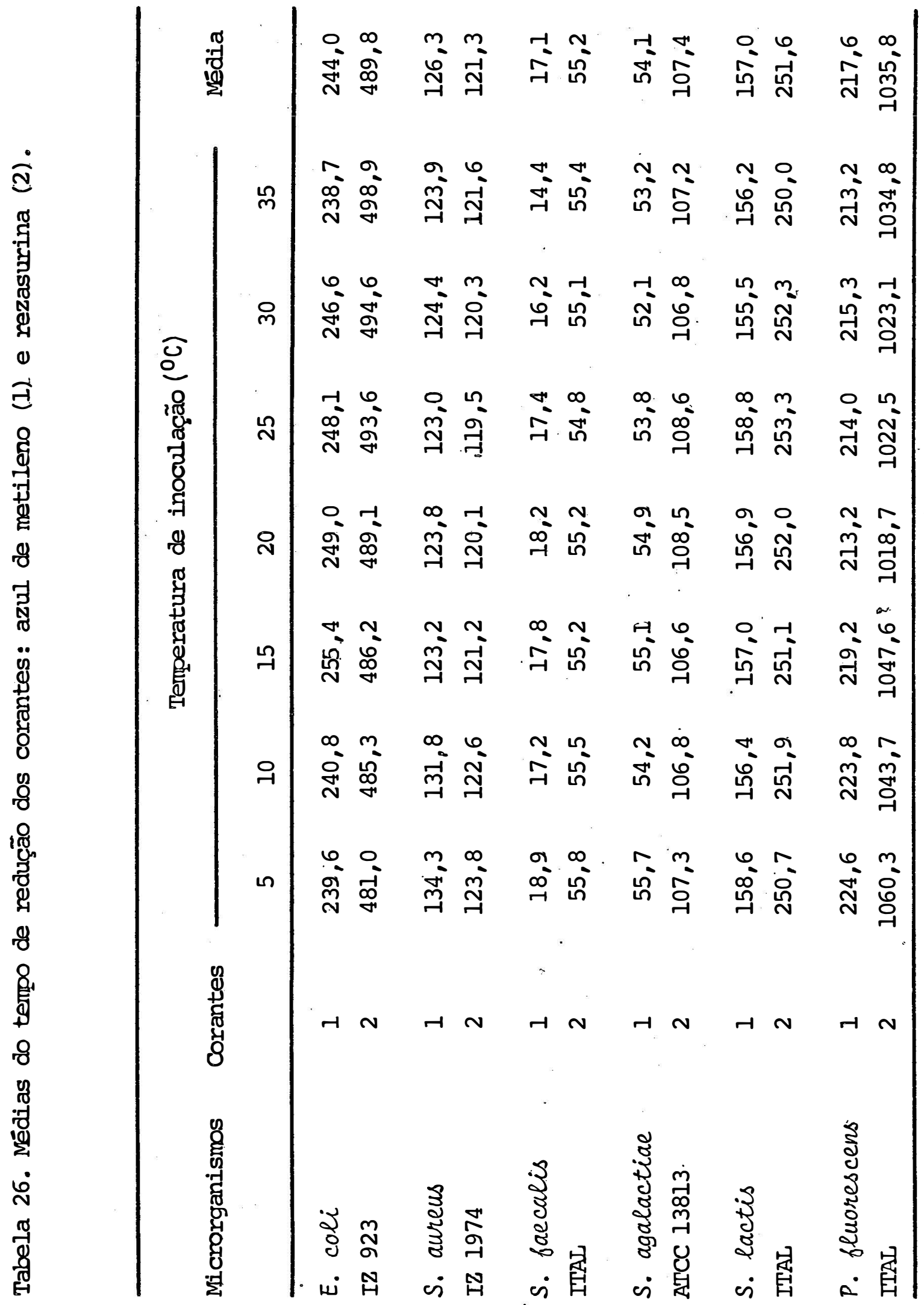

